\title{
Imigração internacional: uma alternativa para os impactos das mudanças demográficas no Brasil?
}

\author{
Helena Nobre de Oliveira* \\ César Augusto Marques da Silva** \\ Antonio Tadeu Ribeiro de Oliveira**
}

\begin{abstract}
A transição demográfica traz consigo inúmeras transformações na estrutura etária, sendo uma delas o envelhecimento populacional. No Brasil, estima-se que $22,6 \%$ da população terá 65 anos ou mais em 2050, cenário semelhante ao vivido atualmente pelos países desenvolvidos. Diante dessas mudanças, debatem-se os limites e potencialidades da migração como uma possível forma de amenização dessa situação. Por um lado, os imigrantes podem integrar a população em idade ativa, constituindo uma parcela importante da mão de obra brasileira futura. Por outro lado, emerge a preocupação que o país seja capaz de absorver esses estrangeiros e que, mais tarde, esses também envelhecerão, aumentando o peso das idades mais envelhecidas. Nesse contexto, surge o termo "migração de reposição", que se refere ao processo migratório com intuito demográfico relativo à estrutura etária ou tamanho populacional. Dessa forma, para analisar o possível impacto da componente migratória sobre a estrutura etária brasileira até o ano de 2050, elaboraram-se projeções demográficas a partir de distintos cenários com base no método das componentes demográficas. Os cenários que objetivaram a atenuação da razão de dependência ou que se basearam em taxas líquidas de migração de países receptores de migrantes, como a Alemanha, foram os que resultaram em saldos migratórios mais razoáveis.
\end{abstract}

Palavras-chave: Migração de reposição. Envelhecimento populacional. Transição demográfica.

\footnotetext{
* Escola Nacional de Ciências Estatísticas (Ence), Instituto Brasileiro de Geografia e Estatística (IBGE), Rio de Janeiro-RJ, Brasil (helenanobre33@hotmail.com; https://orcid.org/0000-0003-1500-3688).

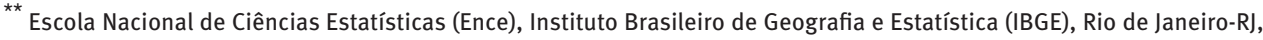
Brasil (cesarmcs@gmail.com; https://orcid.org/0000-0003-4935-112X).

*** Instituto Brasileiro de Geografia e Estatística (IBGE), Rio de Janeiro-RJ, Brasil (tadeu.cidade@gmail.com; https://orcid. org/0000-0001-7128-3210).
} 


\section{Introdução}

A transição demográfica é um fenômeno que traz diversas mudanças na estrutura etária e volume da população, resultantes da queda nas taxas de fecundidade e mortalidade (THOMPSON, 1929; NOTESTEIN, 1945). Atualmente, os países desenvolvidos - assim como classifica a Organização das Nações Unidas (ONU, 1982) - se encontram em estágio avançado de tal processo, o que acarretou uma população com características singulares, especificamente no envelhecimento da estrutura etária, inclusive com aumento relativo da população idosa. ${ }^{1}$ No Brasil, as mudanças demográficas em curso trazem a perspectiva de alterações profundas na estrutura populacional do país para os próximos 30 anos. Seguindo a tendência observada nos anos anteriores, sob a hipótese de queda da fecundidade e também da mortalidade, as projeções populacionais mais recentes elaboradas pelo IBGE $(2013,2018)$ mostram que, até 2050 , esse processo chegará a um novo patamar, no qual a proporção do grupo com idade acima de 65 anos poderá alcançar 21,90\% (IBGE, 2018) ou $22,6 \%$ (IBGE, 2013) da população brasileira, assemelhando-se ao cenário vivido atualmente pelos países desenvolvidos.

Nesse quadro é recorrente a discussão sobre como lidar com as consequências do envelhecimento. Bacci (2012) aponta duas formas de fazê-lo: com a retomada dos níveis de fecundidade ou com o uso da migração. A primeira alternativa seria um caminho de longo prazo, que envolveria o planejamento familiar, aborto, reprodução assistida, entre outros fatores (OLIVEIRA, 2014). Já a migração teria impacto imediato na composição por idades do país, podendo levar, no curto prazo, à amenização das mudanças demográficas em curso.

É nesse âmbito que surge a discussão sobre os limites e as potencialidades da chamada migração de "reposição", caracterizada como uma imigração que expressamente possui intuito demográfico, geralmente atrelado à composição de determinado grupo populacional (COLEMAN, 2001). A ideia seria justificada para o caso brasileiro? Com esse propósito, o presente artigo tem como objetivo analisar como as mudanças demográficas, principalmente no que tange ao envelhecimento populacional, impactarão na dinâmica demográfica futura do Brasil até o ano de 2050, considerando diferentes cenários de imigração internacional.

Para isso é utilizada uma das principais ferramentas da demografia, que são as projeções populacionais. Amplamente utilizadas em diversos campos, as projeções geram subsídios ao desenvolvimento social e econômico e, diante de sua capacidade de

\footnotetext{
${ }^{1}$ Destacam-se as diferenças entre o envelhecimento dos indivíduos e o da estrutura etária. 0 primeiro é um fenômeno "associado a um processo biológico de declínio das capacidades físicas, relacionado a novas fragilidades psicológicas e comportamentais" (CAMARANO, 2004, p. 4). Ainda que não haja consonância sobre qual idade define o idoso (ou mesmo se a idade cronológica é a melhor forma para realizar essa classificação), optou-se pelo uso do limite de 65 anos, a fim de retratar o grupo dos “dependentes" e que, consequentemente, estão fora da força de trabalho. Conforme aponta Camarano, Kanso e Fernandes (2014b), essa idade marca um pico nas taxas de saídas da atividade econômica tanto para homens quanto para mulheres, sendo que para elas a idade de 60 anos também se mostra como um marco para tal evento. Já o envelhecimento da estrutura etária está relacionado a mudanças na distribuição da população por idade, com diminuição do peso relativo das populações jovens e aumento das proporções de adultos e idosos (CARVALHO; GARCIA, 2003; LEE, 1994).
} 
antecipação em relação ao futuro da população, são usadas tanto pelo setor público como pelo privado (NAÇÕES UNIDAS, 1978; PRESTON et al., 2001). No âmbito desse trabalho, foram produzidos quatro cenários de projeções populacionais, com base no método das componentes demográficas. Tais cenários estão especificados a seguir e são detalhados em seção específica sobre os mesmos. 0 cenário “população fechada" supõe uma população com saldo migratório nulo ao longo de todo o período, além de uma queda na fecundidade e na mortalidade para as próximas décadas. 0 cenário "RDI 12" baseia-se na análise de Pereima e Porsse (2013) sobre as formas de minimizar os efeitos do envelhecimento no crescimento econômico, buscando manter, por meio da entrada de imigrantes, a razão de dependência de idosos (RDI) constantemente em 12. Já o cenário “atenuação da RDI” faz uso do crescimento geométrico da RDI chilena (que cresce de forma menos intensa em relação à brasileira) para amenizar esse indicador. Por fim, o cenário "TLM da Alemanha" projeta a entrada de imigrantes a partir da experiência da Alemanha, utilizando no Brasil a mesma taxa líquida de migração (TLM) do país europeu para os próximos anos. A partir de tais cenários, analisamos o impacto potencial da componente migratória sobre a estrutura etária brasileira, discutindo o uso de tal estratégia para atenuar as consequências do envelhecimento populacional.

\section{Transição demográfica no Brasil}

A transição demográfica pode ser definida como um processo social amplo, que alterou profundamente as dinâmicas de natalidade e mortalidade. A partir de uma sucessão de transformações populacionais, as altas taxas de fecundidade e mortalidade foram sucedidas por um quadro em que prevalecem níveis baixos para ambas as taxas (THOMPSON, 1929; NOTESTEIN, 1945). ${ }^{2}$ Tais alterações geram mudanças estruturais significativas, fazendo com que a composição etária da população se transforme gradativamente, passando de uma fase de elevado crescimento populacional e predominância de crianças e jovens para uma nova fase de desaceleração do crescimento e aumento da participação da população de adultos e idosos (SILVA et al., 2007; SIMÕES, 2006).

Na América Latina, esse processo ocorreu de modo acelerado, embora bastante heterogêneo. Em termos gerais, ele foi marcado pela rápida queda da fecundidade a partir da década de 1970 e o contínuo ganho na expectativa de vida, já a partir dos anos 1940 (ZENTENO, 2004; CEPAL, 2005; WONG; CARVALHO; AGUIRRE, 2000; FÍGOLI; WONG, 2003; SAAD; MILLER; MARTINZEZ, 2009). Contudo, esse processo foi heterogêneo em termos de ritmo e intensidade das mudanças. Para a Comissão Econômica para a América Latina e o Caribe (CEPAL, 2008), os países latino-americanos poderiam ser classificados, em função de seus níveis de fecundidade e mortalidade, em quatro etapas distintas da transição: muito

\footnotetext{
${ }^{2}$ Alguns estudos apontam que, na Europa, em algumas regiões, a queda dos níveis de fecundidade antecedeu o declínio das taxas de mortalidade. Nesse sentido, a transição demográfica será abordada neste artigo ancorada naquilo que McKeown (1978) tratou como crescimento moderno da população, período no qual as regularidades entre o declínio da mortalidade e fecundidade podem ser observadas.
} 
avançada, avançada, plena ou moderada. Em uma classificação anterior, Zenteno (2004) considera que o continente possui países nas etapas avançadas, em plena transição, em níveis moderados e, contrariamente à classificação anterior, em níveis ainda incipientes.

No Brasil, esse processo começou entre as décadas de 1940 e 1960, quando teve início a queda da mortalidade, resultado da combinação entre incrementos no padrão de vida da população e avanços na área médica (ALVES, 2014). Enquanto isso, as taxas de fecundidade permaneciam altas, resultando em um rápido crescimento populacional e aumento da participação relativa das faixas etárias mais jovens (CARVALHO; WONG, 1995; CAMARANO; KANSO; FERNANDES, 2014a; SIMÕES, 2006).

A partir dos anos 1960, apesar da ausência de políticas explícitas ligadas à fecundidade, os indicadores dessa componente indicavam uma tendência à queda, que teve início primeiramente nas regiões mais desenvolvidas e grupos sociais mais ricos. Na década seguinte, a tendência foi observada nas demais regiões brasileiras e, também, nos demais grupos sociais (CARVALHO; WONG, 1995; CARVALHO; BRITO, 2005; SIMÕES, 2006).

Nesse contexto, diversas pesquisas ressaltaram que a transição demográfica brasileira, assim como a latino-americana, também é marcada por heterogeneidades, tanto do ponto de vista social como regional. Com isso, os diferencias demográficos entre as regiões não ocorrem apenas em seus níveis de fecundidade e mortalidade, mas também em termos das estruturas etárias e da composição desses grupos em termos de renda (BRITO, 2008; VASCONCELOS; GOMES, 2012; ERVATTI; BORGES; JARDIM, 2015).

De maneira geral, contudo, essa dinâmica traz a tendência de que o topo da estrutura etária seja cada vez mais largo e, paralelamente, tenha uma base cada vez mais estreita. Tais mudanças são indícios de um processo em curso na sociedade brasileira e já vivenciado em países europeus, que convivem com consideráveis proporções de indivíduos nos grupos etários com 65 anos ou mais, em um cenário de avançado envelhecimento populacional.

No Brasil, projeta-se que a estrutura etária da população, em 2050, apresente uma distribuição mais homogênea entre as faixas etárias, com o aumento do peso relativo das idades avançadas (IBGE, 2018). As pessoas com 65 anos ou mais, que em 2010 correspondiam a $7,4 \%$ da população total, passarão a representar $21,9 \%$ ao fim da primeira metade do século XXI, ou seja, serão pouco mais de um a cada cinco habitantes, sendo o grupo etário que mais crescerá em termos absolutos a partir de 2030 (BRITO et al., 2007). Assim:

Em síntese, os cenários para 2050 são de uma população adulta numerosa e entrando em envelhecimento de forma rápida e contínua. É a fase em que o peso dos idosos sobre a população far-se-á sentir mais acentuadamente, dado que sua participação será expressiva no conjunto da população brasileira em meados do século (ALVES; VASCONCELOS; CARVALHO, 2010, p. 17).

Nesse cenário, é projetada uma série de mudanças sociais e econômicas. Alterações na composição familiar e nos arranjos domiciliares (SAAD, 2005), nas demandas por políticas públicas (ALVES; VASCONCELOS; CARVALHO, 2010), nas causas das mortes, que deixarão de ser predominantemente por doenças infecciosas e parasitárias e passarão a ser por 
doenças não transmissíveis e as crônico-degenerativas (SAAD, 2005), nos efeitos ligados à questão previdenciária (BRITO, 2007; OLIVEIRA et al., 2004; TAFNER; BOTELHO; ERBISTI, 2014), além da disponibilidade de mão de obra (BARBOSA, 2014; SOUZA-JUNIOR; LEVY, 2014), são apontadas como possíveis consequências desse processo.

Além disso, o aumento da imigração internacional também traz discussões sobre suas relações com a fecundidade e mortalidade, que poderiam ser diferenciais nos casos dos migrantes e que trariam impactos na transição demográfica. Em ambos os casos, os efeitos são diversos, relacionados a dinâmicas locais e de difícil previsão. As análises sobre a fecundidade de migrantes são mais disseminadas nos estudos demográficos, que principalmente buscam analisar como emigrantes com origem em regiões de alta fecundidade adotariam ou não os padrões dos locais de destino. Esse é o caso de uma série de trabaIhos nos Estados Unidos, que mostram a interferência do comportamento reprodutivo dos imigrantes na amenização da queda da fecundidade, ou até na sua estabilização (KANH, 1994; CARTER, 2000). Já para a mortalidade, as estimativas feitas para casos internacionais indicam que os efeitos são diversos. Page et al. (2007) mostram que, na Austrália, os imigrantes possuíam expectativa de vida levemente superior à dos naturais, enquanto Reus-Pons et al. (2017) apontam que em alguns países europeus a mortalidade dos não migrantes foi levemente superior em relação aos níveis de migrantes. Contudo, em ambos os casos, as diferenças foram baixas, raramente superiores a um ano.

Esse quadro resulta em uma população com características e necessidades distintas daquelas existentes atualmente e no passado. É nesse contexto que emerge a discussão sobre a chamada "migração de reposição".

\section{Migração de reposição}

0 rápido envelhecimento populacional é uma questão fundamental da dinâmica demográfica brasileira. Segundo Oliveira (2014), seria pouco desejável uma população com estrutura etária muito envelhecida, dados os impactos que tal distribuição por grupos de idade poderá acarretar no desenvolvimento econômico e social devido à diminuição da população em idade ativa e, consequentemente, da força de trabalho, cenário iminente no Brasil. Por isso, o autor questiona as medidas possíveis a serem tomadas de modo a tornar esse quadro sustentável.

Segundo Bacci (2012), os dois caminhos possíveis na mitigação dos impactos do envelhecimento populacional são a retomada dos níveis de fecundidade e o incentivo à imigração. Oliveira (2014) aponta que o caminho pautado nas questões de fecundidade envolve diferentes temáticas, como planejamento familiar, aborto, reprodução assistida, entre outros fatores, e é um processo de efeitos a longo prazo. Além disso, o autor ressalta que é pouco razoável considerar que uma fecundidade baixa volte a subir de maneira considerável de modo a afetar o processo em debate, se considerarmos a experiência de outros países. Na Europa, viu-se entre 1998 e 2008 uma tendência de crescimento na TFT 
do conjunto de países como um todo, conforme apontam Bongaarts e Sobotka (2012). Os autores explicam que essa mudança de sentido surge, principalmente, dos nascimentos oriundos de uma geração que postergou a gravidez. Alguns países chegaram a apresentar um aumento de mais 0,5 filho por mulher entre 1999 e 2008, tornando a TFT, que era baixa, um pouco mais próxima do nível de reposição. Ainda que tenha sido observado um aumento na TFT, a Europa continua a enfrentar dificuldades em lidar com o envelhecimento de sua população. 0 crescimento no número de filhos por mulher na medida que ocorreu ainda não foi suficiente para suprir todas as demandas de uma sociedade com um peso maior das idades envelhecidas. Assim, vê-se que, mesmo que seja possível a ocorrência de uma reversão nas tendências de fecundidade, o envelhecimento ainda será uma questão a ser enfrentada, talvez de maneira menos amena, porém, com sua relevância.

Em relação à migração, Rosa (2012, p. 183) afirma que o migrante, que a autora classifica como "laboral”, possui duas características: "concentram-se nas idades ativas, também elas as mais férteis, e possuem, com frequência, níveis de fecundidade superiores". Contudo, a literatura sobre a comparação entre a fecundidade de imigrantes e não imigrantes aponta a diversidade de processos e a dificuldade de apresentar conclusões definitivas. Há aqueles que indicam que a fecundidade do imigrante depende apenas do ambiente onde ele nasceu, não sofrendo influência do país de destino (GOLDBERG, 1960). Outros afirmam que seu comportamento em relação ao número de filhos tende a convergir para o da população do país de destino, que será decisivo na mudança do padrão de fecundidade dos imigrantes (GOLDSTEIN, 1973; UMEZAKI; OHTSUKA, 1998). Uma terceira vertente ressalta que o indivíduo tende a migrar para regiões com padrões de fecundidade semelhantes ao seu (MACISCO et al., 1970) e uma quarta sugere que, devido a dificuldades do processo de migração, há uma ruptura comportamental do imigrante, que faz com que sua fecundidade seja bastante baixa (HERVITZ, 1985). Dentre as quatro hipóteses, como afirma Kulu (2005), a segunda, o modelo de assimilação, seria a com maior força nos estudos mais recentes, considerando a migração internacional. Essas são as conclusões apontadas em diversos contextos: para os Estados Unidos (CAMAROTA; ZIEGLER, 2009); para a Alemanha (MAYER; RIPHAHN, 1999); e para a Estônia (KULU, 2005). No caso da Estônia, por exemplo, os autores mostram que os migrantes, independentemente da sua origem, tendem a adaptar-se aos níveis de fecundidade predominantes no local de destino. Isso ocorreria, principalmente, devido às condições de vida pós-movimento migratório, que limitam de alguma forma o número de filhos que o indivíduo possa querer vir a ter e também novas experiências, vivências e principalmente a cultura no novo ambiente, que acabam por moldar o comportamento de imigrantes.

Nesse quadro, a imigração teria impacto relevante na minimização da velocidade do envelhecimento populacional por gerar o crescimento relativo da população em idade ativa, suavizando o peso relativo das idades mais avançadas. Contudo, em uma perspectiva de médio-longo prazo, ocorrerá também o envelhecimento do imigrante, além da potencial convergência desses a fecundidades dos locais de destino, influenciando assim no próprio 
envelhecimento populacional. Essas são as conclusões sobre a questão para a dinâmica recente dos Estados Unidos, por exemplo (CAMAROTA; ZEIGLER, 2019). Sendo assim, com o passar das décadas, além da população nativa, aquela vinda de imigrantes precisará compensar também o envelhecimento desse grupo que, anteriormente, possibilitou a expansão da força de trabalho.

É nessa discussão que emerge o termo “migração de reposição", que consiste no uso da migração com objetivos demográficos, para suprir déficits populacionais, para atender às necessidades de mão de obra ou ainda para manter indicadores demográficos (geralmente relacionados à razão de dependência entre a população considerada inativa e a ativa) em certo patamar, conforme define a ONU (2001) no relatório Replacement migration: is it a solution to declining and ageing populations? Na publicação, a partir de projeções populacionais para França, Alemanha, Itália, Japão, Coreia do Sul, Rússia, Reino Unido, Estados Unidos e também para a Europa e União Europeia, são analisados o total de imigrantes necessário para atingir quatro cenários distintos. São eles: evitar o decrescimento populacional; manter constante o tamanho da PIA; manter a razão de suporte (razão entre o total de indivíduos de 15 a 64 anos de idade e o total com 65 anos ou mais) sempre acima de 3,0; e, por fim, impedir a queda da razão de suporte.

Como esperado, os cenários trouxeram resultados diferentes, sendo alguns logicamente impossíveis. Esse foi o caso do cenário de manutenção da razão de suporte da Coreia do Sul fixa no valor de 1995 (12,6), em que seria necessária a chegada de mais de cinco bilhões de imigrantes entre 1995 e 2050, o que poderia equivaler à metade da população mundial ou uma média de 93 milhões de entradas anuais (considerando a emigração nula). Esse seria o quantitativo necessário para reverter o declínio da razão de dependência, que chegaria ao valor de 2,4 em 2050, segundo as projeções da ONU.

Com base nesses resultados, Coleman (2001) classificou o volume necessário de imigrantes como utópico. 0 autor mostrou-se bastante cético em relação ao uso da migração como alternativa para lidar com os desafios do envelhecimento populacional, denotando "que não há soluções viáveis para a mudança na estrutura etária e seus efeitos sobre a segurança social" e que "nada trará de volta a estrutura etária de séculos anteriores" (COLEMAN, 2001, p. 12, tradução nossa). 0 autor procura rebater as ideias trazidas pelo relatório da ONU, principalmente por meio do questionamento de que o decaimento da população ou da razão de suporte não seria realmente algo ruim e indesejável, conforme transmitido pelo documento. Meyerson (2001), que também traz críticas ao relatório, afirma que, apesar da visão da publicação, para diversos países o crescimento lento é visto como algo positivo. Ele afirma que, entre as vantagens do declínio populacional, estão a contenção de desequilíbrios ambientais e também a diminuição dos gastos com infraestrutura e, por isso, vê o relatório da ONU como desnecessariamente alarmante.

Assim como Camarano (2014a) sintetiza, há argumentos favoráveis e contrários ao crescimento populacional, em um debate que vem desde, ao menos, a ascensão do Iluminismo. Focar na questão do crescimento populacional e tentar classificá-lo simplesmente como 
benéfico ou maléfico é sinônimo de não compreender a complexidade desse tema, que envolve fatores das esferas econômica, social e política. Fazer uso dessa dicotomia é "assumir um padrão tecnológico constante, uma oferta inelástica de recursos e um padrão estático da distribuição destes diante de um crescimento acelerado do segmento jovem ou idoso" (CAMARANO, 2014a), ou seja, é supor que toda a tecnologia e a vida humana não podem se adaptar a mudanças. Dessa forma, o crescimento baixo, por si só, não é ruim ou fatal. Como destaca Camarano (2014b, p. 199):

[...] demografia não é um destino. Ao longo da História, pode-se observar que as mudanças demográficas sempre criaram desafios importantes para as sociedades. Mas a sociedade sempre fez opções políticas para se adaptar a elas. Ou seja, as mudanças demográficas em si mesmas não são boas nem ruins; boas ou ruins são as maneiras que a sociedade escolhe para lidar com elas.

É desse modo que Coleman (2001) critica o viés puramente demográfico do relatório da ONU sobre a relação migração e envelhecimento populacional. Haveria outras estratégias - de cunho não demográfico - que poderiam ser utilizadas, gerando impacto sobre o processo em questão e que não tiveram a ênfase merecida. Alterações nos limites de idade da PIA e PEA, nos sistemas previdenciários, nas taxas de produtividade e nas taxas de atividade seriam fundamentais para retratar o cenário futuro de maneira mais verossímil possível. Nesse caso, a migração teria um papel importante e o tema mereceria maior atenção, mas não com ênfase em um viés puramente demográfico. 0 autor defende que a preocupação sobre as dinâmicas sociais e econômicas, e não simplesmente do nível em que se encontram os indicadores demográficos, seriam, portanto, as principais (mas não únicas) questões de investigação. Do ponto de vista demográfico, a preocupação central seria a sustentabilidade ou não das razões de dependência projetadas para o futuro, e não as consequências do declínio da população. Assim, apesar da importância do cenário econômico e fiscal para o enfrentamento das questões levantadas, seria importante assumir a relevância das questões demográficas atreladas a elas e, consequentemente, a influência que as variáveis relacionadas à população poderiam exercer.

No que tange à migração, Coleman (2001) cita que, embora possa ser relativamente possível iniciar uma corrente migratória em direção a um país, haveria grande dificuldade em impor obstáculos para que essa fosse interrompida no futuro, principalmente usando justificativas puramente demográficas. Ainda conforme o autor, a população cresceria a taxas econômica e ambientalmente insustentáveis de maneira permanente e radical, alterando a composição étnica e cultural e substituindo toda a população do país receptor. De maneira complementar, Meyerson (2001) afirma que isso apenas retardaria o envelhecimento populacional, que seria praticamente inevitável. Além disso, ele afirma que, somado aos pressupostos frágeis, existe também o problema de que a projeção na qual se baseia o estudo é feita para 2050, ou seja, é de longo prazo e possui maior chance de erro. Portanto, o autor defende ser arriscado se basear em cálculos tão delicados para desenhar políticas no campo da migração. 
Contudo, apesar das controvérsias sobre os efeitos da imigração internacional, já foi apontado que diversos países buscam enfrentar as questões relacionadas ao envelhecimento populacional por meio dessa prática e, ainda assim, não crescem descontroladamente conforme é sugerido. 0 controle sobre o fluxo de imigrantes é mantido continuamente. Além disso, em relação às projeções, cabe ressaltar que elas se tornam relevantes para análises futuras, podendo contribuir nos mais variados eixos temáticos. São estimativas feitas como possibilidades para o futuro. Uma das poucas certezas sobre projeções demográficas é que essas divergem da população observada, o que não as inviabiliza. Essas podem e são feitas como instrumentos que subsidiam o planejamento e informam melhor sobre potenciais ações e efeitos de dinâmicas sociais e demográficas.

No que diz respeito à prática da migração de reposição, Beaujot (2003) verifica o impacto dessa componente no Canadá, enquanto Bijak, Kupiszewska e Kupiszewski (2008) assinalam o efeito dessa prática em 27 países da Europa. Ambas as análises criam distintos cenários para verificar a demanda por imigração.

Para o Canadá, Beaujot (2003) considera que a chegada de imigrantes pode ser uma das estratégias às consequências da baixa fecundidade. Para o país, entre 1991 e 2001, quase $60 \%$ do crescimento populacional observado deveu-se ao saldo migratório positivo do período. Apesar de toda a discussão sugerida pelo autor sobre migração de reposição no Canadá, ele levanta críticas semelhantes às feitas por Coleman (2001).

Bijak, Kupiszewska e Kupiszewski (2008) defendem que um fluxo maior de imigrantes com destino à Europa amenizaria o problema de oferta de mão de obra no seu mercado de trabalho. Assim, os autores concluem que apenas o cenário acerca do crescimento populacional não traria fortes consequências políticas e sociais, principalmente no que tange à composição da população. Eles defendem que um misto entre políticas de fecundidade e incentivo à participação na força de trabalho, além de imigração em um nível razoável, poderia funcionar em conjunto como uma estratégia para minimizar os impactos do envelhecimento populacional. Nesse âmbito, a antecipação das medidas seria central.

Nesse contexto, a migração se reafirma como um componente importante também nos estudos sobre composição etária da população. Não só a entrada de migrantes e a dinâmica do saldo migratório são relevantes, mas também a forma como esse processo é encarado, sendo fundamentais os debates acerca do tema para que as políticas migratórias caminhem no sentido de garantia dos direitos desse grupo.

\section{A questão migratória no Brasil e no mundo}

O potencial cenário de elevação do saldo migratório internacional no Brasil, com efeitos relacionados à migração de reposição, é fortemente dependente da adoção e do estímulo de políticas públicas que caminhem nessa direção. Contudo, a história da migração brasileira é pautada em diferentes momentos e visões sobre o migrante, tendo início com a própria chegada de europeus na chamada Era das Navegações. No período em que as especiarias 
movimentavam o mundo, buscar uma nova rota para a Índia e também novas terras para exploração passou a ser objetivo daqueles que comandavam as expedições marítimas da época (BACCI, 2012). Essa movimentação possibilitou o contato com outros povos e, inclusive, a chegada dos portugueses no Brasil em 1500.

Após essa chegada e começo do cultivo de cana-de-açúcar no país, teve início o movimento migratório em direção ao Brasil, quando se fez necessária a vinda de mão de obra de diferentes nacionalidades para a nova colônia portuguesa. A primeira fase desse período é marcada por uma migração numerosa e compulsória de escravos africanos. É, portanto, um movimento migratório apenas do ponto de vista demográfico, ou seja, houve a mudança de território, sem um processo de escolha ou autonomia nessa decisão. Sob tais circunstâncias, Bacci (2002) estima - de maneira corajosa, como ele mesmo diz - que tenham sido trazidos ao Brasil cerca de dois milhões de africanos até o ano de 1800. Comparativamente, no mesmo período, o autor estima a chegada de 600 mil indivíduos de outras nacionalidades.

Paralelamente, entre o final do século XIX e início do XX, houve subsídio estatal para estimular a imigração europeia para o Brasil com a preocupação de povoar a colônia com indivíduos brancos e "cultos", e também de protegê-la (SEYFERT, 2002). Poucos anos depois, na década de 1840, com a expansão cafeeira, o estímulo a esse processo passou a ser dado pela iniciativa privada (IOTTI, 2010). A vinda de europeus ao país perdeu seu cunho colonizador do período anterior e passou a ter o intuito de atrair trabalhadores, já que esses estavam escassos após a flexibilização da escravidão. Esse processo deu-se de maneira mais fácil, já que o momento demográfico da Europa favorecia a emigração em massa: um excedente populacional em um momento de urbanização e diminuição dos empregos no continente levou à entrada de 4,07 milhões de estrangeiros no Brasil (LEVY, 1972).

Ao longo dos anos seguintes, a abordagem em relação à temática no país se transformou, passando por fases com cunho restritivo e um processo de queda no número de entradas de estrangeiros, até chegar à década de 1980, quando ocorreu um marco em relação às políticas ligadas aos imigrantes internacionais. Quando o país ainda se encontrava sob o regime militar, instituiu-se o Estatuto do Estrangeiro, por meio da Lei n. 6.815, baseada no estereótipo de que o estrangeiro seria uma ameaça à segurança do país (OLIVEIRA, 2015a). Foi também nesta década que, depois de alguns anos com saldo migratório próximo a zero, houve um aumento na emigração causado, principalmente, pela recessão e reestruturação econômica brasileira, o que resultou na diminuição de empregos formais (MARTES, 2001). Exercícios realizados por Carvalho (1996) e Oliveira et al. (1996) estimaram um saldo migratório negativo no período em aproximadamente 1,5 milhão de pessoas, com emigrações direcionadas aos Estados Unidos e Europa. Segundo Patarra e Fernandes (2011), nesse período, o principal país de destino dos emigrantes foi os Estados Unidos, com parte portando visto, mas permanecendo mesmo após seu vencimento, como imigrante irregular. Já no final do século, Portugal e Espanha também entraram na rota de migração de brasileiros, tornando-se os principais destinos europeus nesse período (PATARRA; FERNANDES, 2011). 
Esse quadro foi retrato não somente do momento econômico vivenciado pelo Brasil, mas também de um fenômeno vivido mundialmente. Como Martine (2005) denota, a globalização, expressa pela integração econômica criada e gerenciada no âmbito do liberalismo (muito embora de forma incompleta e parcial), interfere nos deslocamentos espaciais da população na medida em que possibilita que o horizonte do migrante seja o próprio "mundo". Contudo, seus resultados e contradições, que ampliam desigualdades internacionais e fomentam a livre circulação do capital e serviços, resultam em regras que não são válidas em relação à imigração internacional, em que há restrição dos deslocamentos. É nesse âmbito que diversos países entram na rota das migrações internacionais, atuando como receptores e emissores de população simultaneamente. Segundo Arango (2007, p. 8), é possível até mesmo falar em uma "nova era na história das migrações internacionais", com características distintas de todas as observadas até então. Essa nova era se distingue não só pelo contexto em que ocorre e pela existência de múltiplos países de origem e destino, mas também pela intensidade dos fluxos e consequências desse processo.

Diante da acentuação desse processo, os imigrantes e seus descendentes tornam-se, cada vez mais, uma parcela considerável da população em determinados países. Estima-se, por exemplo, que no caso da Holanda, os imigrantes e seus descendentes serão seis milhões - o equivalente a $30 \%$ - de um total de 18 milhões de habitantes estimados para 2030 no país (COLEMAN, 2001). Um quadro como esse aumenta a preocupação em relação à perda de identidade cultural, principal receio dos indivíduos dos países receptores, segundo Arango (2007). Stavenhagen (1994) explica que a ideia de uma raça superior - seja racial, psicológica ou culturalmente - surgiu ainda no processo de formação dos Estados nacionais modernos. No período da colonização, era necessário um discurso que legitimasse a ação dos colonizadores e, portanto, esse sentimento cresceu com tal propósito. Ainda que no contexto de globalização, quando as nações tenderiam à multiculturalidade, essa ideia pareça contraditória, o sentimento de Estado nacional com uma cultura homogênea - muitas vezes associado a um território - ainda persiste. Portanto, o autor afirma que o surgimento de movimentos xenofóbicos e racistas não pode ser compreendido como algo dissociado desse contexto histórico. Segundo ele, essas ideologias provaram ser incapazes de romper com o passado e o racismo institucionalizado e enfrentar as novas realidades multiculturais trazidas pelo processo de globalização. Com isso, grupos contrários à imigração são cada vez mais comuns e numerosos, disseminando ideias extremistas e aumentando os casos de xenofobia, intolerância e preconceito em relação aos imigrantes. Tais questões ganham centralidade no debate sobre a migração de reposição, e qualquer tentativa de alavancar políticas migratórias demandaria sua desconstrução, inclusive (mas não somente) do ponto de vista pedagógico. Para Canen (2014, p. 93), as medidas devem buscar superar "a essencialização das identidades", com:

[...] atividades pedagógicas que busquem: desconstruir estereótipos; valorizar os grupos e identidades oprimidos; problematizar a pouca representatividade desses grupos em espaços sociais, políticos e no currículo; e contextualizar historicamente os mecanismos que marginalizaram estes grupos do poder político, econômico e social. 
Diante dos problemas oriundos da migração, que se trata de uma problemática globalizada, esta vem sendo enfrentada por diversos países de maneira distinta. Uma das principais características desse período reside no fato de que, apesar de os fluxos migratórios serem intensos, as fronteiras já não são mais livres (ARANGO, 2007). As demarcações, limitações e barreiras são mais claras e, em uma série de casos, estimuladas. Segundo Oliveira (2015a, p. 260), “os imigrantes, que nos anos de expansão econômica eram vistos como importantes no processo de crescimento econômico, passam a ser enxergados como indesejáveis e a quem se deve negar direitos e combater a presença”. As políticas atuais possuem cada vez mais um caráter restritivo, buscam limitar a entrada de indivíduos e selecionar as características que melhor se adequam às necessidades do país receptor. Arango (2007) levanta a ideia de que, enquanto vive-se em um mundo globalizado, onde informação e mercadoria são globalizadas, há a limitação do trânsito de pessoas, formando o que o autor chama de "globalização fronterizada" (ARANGO, 2007, p. 10), repleta de barreiras ao deslocamento. Contudo, inclusive nesse âmbito, é interessante notar que o debate sobre a migração de reposição pode favorecer a desconstrução das restrições à migração. Uma vez que o aumento da componente migratória pode suprir demandas do mercado de trabalho e diminuir a pressão sobre a previdência - já que tem grande potencial de aumento da parcela em idade ativa -, o debate acerca desse assunto contribui para desconstruir argumentos favoráveis ao endurecimento das regras em posturas antimigratórias. Isso ocorre, pois, enquanto as justificativas favoráveis permeiam os campos demográfico, econômico e dos direitos humanos; aquelas contrárias fundamentam-se basicamente em certas posições nacionalistas e na preocupação com o tamanho populacional, mostrando que as ameaças relacionadas à atração de imigrantes tornam-se pequenas se comparadas às suas potencialidades. Assim, há um conjunto de países que investem em políticas voltadas para a atração de imigrantes, mas a partir de uma concepção baseada na seleção dos tipos de imigrante que se deseja, ou seja, nos atributos que irão favorecer a economia. Um exemplo disso é o Canadá, que em 2013 foi o oitavo do mundo em número de estrangeiros (ONU, 2013). A política atrativa canadense consiste em facilitar a entrada daqueles que se adequam ao perfil desejado. Indivíduos com fluência na língua nativa, jovens e qualificados conseguem mais facilmente autorização para imigrar, já que possuem as características consideradas ideais para impulsionar a economia e conter as mudanças demográficas em curso no país (RUEDIGER, 2015).

Já a abordagem dos Estados Unidos diferencia-se significativamente do Canadá, pois busca muito mais o controle das fronteiras e a seleção das características almejadas no migrante do que realmente atraí-los. Os Estados Unidos, assim como grande parte dos países receptores, optam por imigrantes qualificados que possam se inserir no mercado de trabalho nas áreas que o país possui maior necessidade, fornecendo vistos temporários e permanentes (RUEDIGER, 2015).

No Brasil, que vivencia um quadro em que as imigrações e emigrações praticamente se anulam e pouco avançava em relação a políticas migratórias, observou-se um incremento das imigrações no final dos anos 2000 e início da década de 2010, com a entrada de sul-americanos, 
migrantes do Norte Global (americanos, espanhóis, portugueses, italianos, franceses, alemães, etc.), haitianos, africanos, chineses e, por último, venezuelanos. Isso ocorreu em um contexto de grandes mudanças sociais no Brasil, dada a combinação de fatores internos e externos, entre outros aspectos, como o bom momento econômico brasileiro, ao contrário do observado na maioria dos países de origem dessa imigração; com políticas de inclusão e distribuição de renda no plano social; elaboração do Acordo de Residência do Mercosul; e mudanças do papel almejado pelo Brasil no cenário internacional, buscando assento no Conselho de Segurança da ONU. É nesse momento que os dados evidenciam um retorno dos brasileiros que viviam no exterior. Oliveira (2013) mostra que, dos indivíduos que entraram no país entre 2005 e 2010 captados no Censo Demográfico de 2010, 65\% eram nascidos no Brasil, em um movimento que ocorreu independentemente de políticas públicas específicas de imigração.

Em relação aos imigrantes internacionais no período recente, cresce um grupo específico que é o de refugiados. Segundo o relatório Refúgio em números (BRASIL, 2017), entre 2010 e 2017, foram recebidas pelo país mais de 120 mil solicitações de refúgios, sendo a maioria de venezuelanos e haitianos. Os haitianos, após o terremoto de 2010, tiveram o ápice no número de solicitações em 2014, alcançando mais de 16 mil pedidos.

Já a chegada de venezuelanos corresponde a processos mais recentes, decorrentes da grave crise econômica do país. Enquanto em 2016 foram menos de 4 mil pedidos de refúgio, em 2017 ocorreram quase 18 mil solicitações. É importante ressaltar que esses números referem-se apenas aos solicitantes de refúgio, e não exatamente aos refugiados. De modo geral, tais movimentos são múltiplos: há aqueles que entraram no país de maneira legal, porém de outra forma, ou ainda aqueles que entraram sem autorização (PATARRA; FERNANDES, 2011). Seriam movimentos mistos, em que há uma diversidade de fatores e motivos de migração, com múltiplas modalidades em um fluxo (SILVA; BOGUS; SILVA, 2017).

No caso das migrações venezuelanas, seu rápido crescimento tem gerado diversos conflitos na fronteira entre os países, principalmente no estado de Roraima. As consequências dessas entradas e os embates gerados mostram que a complexidade e heterogeneidade do processo indicam tanto as dificuldades teórico-metodológicas para a compreensão do fenômeno como a demanda pela construção de políticas migratórias e de integração (BAENINGER; SILVA, 2018). Ainda, é importante destacar que essas entradas não foram suficientes para impactar significativamente o tamanho ou a composição etária da população no país (OLIVEIRA, 2017).

Em relação às abordagens da temática migratória no Brasil, foi sancionada e regulamentada, em 2017, a Nova Lei de Migração. Apesar dos diversos vetos em relação à proposta original, a lei foi vista como um passo positivo em direção ao futuro de políticas migratórias inclusivas no país.

Diante dos exemplos discutidos, nota-se que cada país possui uma visão predominante acerca da migração e suas consequências. Nesse sentido, a discussão sobre migração de reposição emerge trazendo uma potencialidade dessa componente, mostrando que a ação pode ser benéfica para o país receptor, diminuindo, assim, as resistências a essa prática. 
Para melhor analisar o caso brasileiro em relação à estratégia da migração de reposição, mesmo sabendo da essencialidade de existirem políticas migratórias favoráveis à prática e que essas ainda estão em processo de estruturação, foram propostos cenários com diferentes hipóteses acerca da componente migratória para avaliar tal estratégia como alternativa às consequências do envelhecimento populacional.

\section{Cenários projetados}

Nesse artigo realizou-se a projeção populacional da população do Brasil até o ano de 2050, tomando 2016 como ano de partida. Para tal utilizamos valores determinísticos de fecundidade, mortalidade e migração, com o uso do método das componentes demográficas. A elaboração dos cálculos foi feita por meio do programa Rural-Urban Projection (RUP), criado pelo United States Census Bureau, agência governamental dos Estados Unidos que também é responsável pelo Censo Demográfico americano.

Os pressupostos assumidos diferenciam-se entre os cenários, principalmente, no que tange à migração. Para essa componente, cada cenário teve uma hipótese em relação ao tamanho do saldo migratório, mas manteve a estrutura etária dos migrantes. Para a estimativa dessa estrutura etária, considerou-se que, apesar de a migração ser um fenômeno que ocorre em todas as faixas etárias, há consonância sobre sua concentração nas idades ativas (ROSA, 2012). Levou-se em conta também que o aumento expressivo no número de imigrantes que chegariam ao Brasil durante os próximos anos dependeria de um cenário de estímulos à imigração por meio de políticas públicas, o que geraria um perfil de atração com foco nos grupos em idade produtiva, considerando que os demais grupos de idade seriam uma parcela residual dos imigrantes. 0 objetivo desses cenários foi analisar quais os possíveis impactos demográficos da imigração, construindo cenários condicionais.

Em relação à fecundidade, Carvalho, Gonçalves e Silva (2016) mostraram que a técnica P/F de Brass, quando aplicada aos dados do Censo de 2010, pode resultar em uma sobrestimação da fecundidade. Os autores explicam que isso ocorreu devido à queda das taxas específicas de fecundidade das mulheres de 15 a 19 anos entre os Censos de 2000 e 2010 , o que leva à quebra de um pressuposto da técnica utilizada. Sendo assim, espera-se que os resultados apresentados nas projeções populacionais (IBGE, 2013) estejam superestimando a TFT no Brasil para o período inicial de análise. Além disso, a queda constante prevista para a TFT no cálculo da projeção (IBGE, 2013) não foi observada, o que levou a uma subestimação nos anos seguintes. Por isso, optou-se por fazer uso das estimativas da ONU (2015) de fecundidade. ${ }^{3}$ Contudo, é importante ressaltar que essas não trazem o valor "real" da TFT, já que também poderiam estar sobrestimando a TFT no período inicial da análise, conforme apontado por Castanheira e

\footnotetext{
${ }^{3}$ Durante a execução do presente trabalho, a revisão 2018 das projeções demográficas feitas pelo IBGE (2018) ainda não haviam sido divulgadas.
} 
Kohler (2015). Ainda assim, essa seria uma melhor alternativa, já que supõe uma queda menos acentuada do que aquela prevista pelo IBGE (2013), conforme aponta a Tabela 1. Portanto, para a estimativa da fecundidade, utilizou-se uma combinação entre o nível estimado pela ONU e o padrão da sua estimação pelo IBGE (Tabela 2). Dessa forma, as estimativas utilizadas consideram que, ao final do ano de 2050, o Brasil terá uma TFT de 1,68 filho por mulher (Tabela 3). Ressalta-se que esses valores foram aderentes ao resultado mais recente do IBGE (2018), que estimou TFTs mais altas em relação à revisão anterior.

TABELA 1

Taxas de fecundidade total estimadas (1)

Brasil - 2010-2045

\begin{tabular}{ccc}
\hline Anos & IBGE & ONU (2) \\
\hline 2010 & 1,87 & 1,82 \\
2015 & 1,72 & 1,74 \\
2020 & 1,61 & 1,69 \\
2025 & 1,55 & 1,66 \\
2030 & 1,51 & 1,65 \\
2035 & 1,50 & 1,65 \\
2040 & 1,50 & 1,66 \\
2045 & 1,50 & 1,67 \\
\hline
\end{tabular}

Fonte: IBGE (2013); ONU (2015).

(1) Número médio de filhos por mulher.

(2) Os dados da ONU referem-se ao quinquênio iniciado no ano indicado.

TABELA 2

Taxas específicas de fecundidade e taxa de fecundidade total (1) Brasil - 2010-2050

\begin{tabular}{ccccccccc}
\hline Anos & 15-19 anos & 20-24 anos & 25-29 anos & 30-34 anos & 35-39 anos & 40-44 anos & 45-49 anos & TFT \\
\hline 2010 & 0,0661 & 0,1010 & 0,0896 & 0,0672 & 0,0370 & 0,0111 & 0,0017 & 1,87 \\
2015 & 0,0594 & 0,0900 & 0,0821 & 0,0642 & 0,0355 & 0,0105 & 0,0016 & 1,72 \\
2020 & 0,0451 & 0,0737 & 0,0778 & 0,0700 & 0,0420 & 0,0124 & 0,0018 & 1,61 \\
2025 & 0,0358 & 0,0634 & 0,0751 & 0,0737 & 0,0462 & 0,0136 & 0,0018 & 1,55 \\
2030 & 0,0299 & 0,0568 & 0,0735 & 0,0760 & 0,0488 & 0,0143 & 0,0018 & 1,51 \\
2035 & 0,0299 & 0,0569 & 0,0736 & 0,0761 & 0,0488 & 0,0143 & 0,0018 & 1,51 \\
2040 & 0,0299 & 0,0569 & 0,0736 & 0,0762 & 0,0489 & 0,0144 & 0,0018 & 1,51 \\
2045 & 0,0299 & 0,0569 & 0,0736 & 0,0762 & 0,0489 & 0,0144 & 0,0018 & 1,51 \\
2050 & 0,0299 & 0,0569 & 0,0736 & 0,0762 & 0,0489 & 0,0144 & 0,0018 & 1,51 \\
\hline
\end{tabular}

Fonte: IBGE (2013)

(1) Número médio de filhos por mulher. 
TABELA 3

Taxas específicas de fecundidade (1) ajustadas segundo o nível das projeções das Nações Unidas Brasil - 2010-2050

\begin{tabular}{ccccccccc}
\hline Anos & 15-19 anos & 20-24 anos & 25-29 anos & 30-34 anos & 35-39 anos & 40-44 anos & 45-49 anos & TFT \\
\hline 2010 & 0,0643 & 0,0983 & 0,0872 & 0,0654 & 0,0360 & 0,0108 & 0,0017 & 1,82 \\
2015 & 0,0603 & 0,0915 & 0,0834 & 0,0652 & 0,0361 & 0,0106 & 0,0017 & 1,74 \\
2020 & 0,0473 & 0,0772 & 0,0816 & 0,0734 & 0,0441 & 0,0130 & 0,0018 & 1,69 \\
2025 & 0,0385 & 0,0681 & 0,0807 & 0,0791 & 0,0496 & 0,0146 & 0,0019 & 1,66 \\
2030 & 0,0328 & 0,0624 & 0,0807 & 0,0834 & 0,0535 & 0,0157 & 0,0020 & 1,65 \\
2035 & 0,0328 & 0,0623 & 0,0806 & 0,0834 & 0,0535 & 0,0157 & 0,0020 & 1,65 \\
2040 & 0,0329 & 0,0625 & 0,0809 & 0,0837 & 0,0537 & 0,0158 & 0,0020 & 1,66 \\
2045 & 0,0331 & 0,0629 & 0,0815 & 0,0843 & 0,0541 & 0,0159 & 0,0020 & 1,67 \\
2050 & 0,0334 & 0,0634 & 0,0821 & 0,0850 & 0,0546 & 0,0160 & 0,0020 & 1,68 \\
\hline
\end{tabular}

Fonte: IBGE (2013); ONU (2015).

(1) Número médio de filhos por mulher.

Em relação à mortalidade, foram utilizadas as estimativas feitas pelo IBGE (2013), baseadas nas tábuas de mortalidade de 2000 e 2010, tendo como limite padrão a mortalidade dos países com maior longevidade do mundo, hipóteses mantidas na Revisão 2018 (IBGE, 2018). Esses valores encontram-se resumidos nas Tabelas 4 e 5.

TABELA 4

Hipótese sobre mortalidade masculina, segundo grupos de idade Brasil - 2010-2050

\begin{tabular}{|c|c|c|c|c|c|c|c|c|c|}
\hline $\begin{array}{c}\text { Grupos de } \\
\text { idade }\end{array}$ & 2010 & 2015 & 2020 & 2025 & 2030 & 2035 & 2040 & 2045 & 2050 \\
\hline Menos de 1 ano & 0,019 & 0,015 & 0,013 & 0,011 & 0,010 & 0,009 & 0,008 & 0,008 & 0,008 \\
\hline $1-4$ & 0,001 & 0,001 & 0,001 & 0,000 & 0,000 & 0,000 & 0,000 & 0,000 & 0,000 \\
\hline $5-9$ & 0,000 & 0,000 & 0,000 & 0,000 & 0,000 & 0,000 & 0,000 & 0,000 & 0,000 \\
\hline $10-14$ & 0,000 & 0,000 & 0,000 & 0,000 & 0,000 & 0,000 & 0,000 & 0,000 & 0,000 \\
\hline $15-19$ & 0,002 & 0,002 & 0,001 & 0,001 & 0,001 & 0,001 & 0,001 & 0,001 & 0,001 \\
\hline $20-24$ & 0,003 & 0,003 & 0,002 & 0,002 & 0,002 & 0,002 & 0,002 & 0,002 & 0,001 \\
\hline $25-29$ & 0,003 & 0,003 & 0,002 & 0,002 & 0,002 & 0,002 & 0,002 & 0,002 & 0,001 \\
\hline $30-34$ & 0,003 & 0,003 & 0,002 & 0,002 & 0,002 & 0,002 & 0,002 & 0,002 & 0,002 \\
\hline $35-39$ & 0,004 & 0,003 & 0,003 & 0,003 & 0,002 & 0,002 & 0,002 & 0,002 & 0,002 \\
\hline $40-44$ & 0,005 & 0,004 & 0,004 & 0,003 & 0,003 & 0,003 & 0,003 & 0,003 & 0,002 \\
\hline $45-49$ & 0,006 & 0,006 & 0,005 & 0,005 & 0,004 & 0,004 & 0,004 & 0,004 & 0,004 \\
\hline $50-54$ & 0,009 & 0,008 & 0,007 & 0,007 & 0,006 & 0,006 & 0,006 & 0,005 & 0,005 \\
\hline $55-59$ & 0,013 & 0,012 & 0,011 & 0,010 & 0,009 & 0,009 & 0,008 & 0,008 & 0,008 \\
\hline $60-64$ & 0,018 & 0,016 & 0,015 & 0,014 & 0,013 & 0,013 & 0,012 & 0,012 & 0,012 \\
\hline $65-69$ & 0,027 & 0,024 & 0,022 & 0,021 & 0,020 & 0,019 & 0,018 & 0,018 & 0,017 \\
\hline $70-74$ & 0,040 & 0,037 & 0,034 & 0,032 & 0,031 & 0,029 & 0,029 & 0,028 & 0,027 \\
\hline 75-79 & 0,061 & 0,056 & 0,053 & 0,050 & 0,047 & 0,045 & 0,044 & 0,043 & 0,042 \\
\hline $80-84$ & 0,090 & 0,084 & 0,079 & 0,075 & 0,072 & 0,069 & 0,067 & 0,066 & 0,065 \\
\hline $85-89$ & 0,134 & 0,125 & 0,118 & 0,113 & 0,108 & 0,105 & 0,102 & 0,100 & 0,099 \\
\hline $90+$ & 0,198 & 0,191 & 0,185 & 0,180 & 0,177 & 0,175 & 0,173 & 0,171 & 0,170 \\
\hline
\end{tabular}

Fonte: IBGE (2013). 
TABELA 5

Hipóteses sobre mortalidade feminina, segundo grupos de idade

Brasil - 2010-2050

\begin{tabular}{llllllllll}
\hline $\begin{array}{c}\text { Grupos de } \\
\text { idade }\end{array}$ & $\mathbf{2 0 1 0}$ & $\mathbf{2 0 1 5}$ & $\mathbf{2 0 2 0}$ & $\mathbf{2 0 2 5}$ & $\mathbf{2 0 3 0}$ & $\mathbf{2 0 3 5}$ & $\mathbf{2 0 4 0}$ & $\mathbf{2 0 4 5}$ & $\mathbf{2 0 5 0}$ \\
\hline Menos de 1 ano & 0,016 & 0,013 & 0,011 & 0,009 & 0,008 & 0,008 & 0,007 & 0,007 & 0,007 \\
$1-4$ & 0,001 & 0,001 & 0,000 & 0,000 & 0,000 & 0,000 & 0,000 & 0,000 & 0,000 \\
$5-9$ & 0,000 & 0,000 & 0,000 & 0,000 & 0,000 & 0,000 & 0,000 & 0,000 & 0,000 \\
$10-14$ & 0,000 & 0,000 & 0,000 & 0,000 & 0,000 & 0,000 & 0,000 & 0,000 & 0,000 \\
$15-19$ & 0,001 & 0,000 & 0,000 & 0,000 & 0,000 & 0,000 & 0,000 & 0,000 & 0,000 \\
$20-24$ & 0,001 & 0,001 & 0,000 & 0,000 & 0,000 & 0,000 & 0,000 & 0,000 & 0,000 \\
$25-29$ & 0,001 & 0,001 & 0,001 & 0,001 & 0,001 & 0,000 & 0,000 & 0,000 & 0,000 \\
$30-34$ & 0,001 & 0,001 & 0,001 & 0,001 & 0,001 & 0,001 & 0,001 & 0,001 & 0,001 \\
$35-39$ & 0,001 & 0,001 & 0,001 & 0,001 & 0,001 & 0,001 & 0,001 & 0,001 & 0,001 \\
$40-44$ & 0,002 & 0,002 & 0,002 & 0,002 & 0,001 & 0,001 & 0,001 & 0,001 & 0,001 \\
$45-49$ & 0,003 & 0,003 & 0,003 & 0,003 & 0,002 & 0,002 & 0,002 & 0,002 & 0,002 \\
$50-54$ & 0,005 & 0,004 & 0,004 & 0,004 & 0,003 & 0,003 & 0,003 & 0,003 & 0,003 \\
$55-59$ & 0,007 & 0,006 & 0,006 & 0,005 & 0,005 & 0,005 & 0,005 & 0,005 & 0,004 \\
$60-64$ & 0,011 & 0,010 & 0,009 & 0,008 & 0,008 & 0,007 & 0,007 & 0,007 & 0,007 \\
$65-69$ & 0,017 & 0,015 & 0,014 & 0,013 & 0,012 & 0,011 & 0,011 & 0,011 & 0,011 \\
$70-74$ & 0,026 & 0,024 & 0,022 & 0,020 & 0,019 & 0,018 & 0,018 & 0,017 & 0,017 \\
$75-79$ & 0,042 & 0,038 & 0,035 & 0,033 & 0,031 & 0,030 & 0,028 & 0,028 & 0,027 \\
$80-84$ & 0,069 & 0,062 & 0,058 & 0,054 & 0,050 & 0,048 & 0,046 & 0,045 & 0,044 \\
$85-89$ & 0,111 & 0,101 & 0,093 & 0,086 & 0,081 & 0,077 & 0,074 & 0,072 & 0,070 \\
$90+$ & 0,163 & 0,155 & 0,149 & 0,144 & 0,141 & 0,138 & 0,136 & 0,134 & 0,133 \\
\hline
\end{tabular}

Fonte: IBGE (2013).

Para a migração foram considerados quatro diferentes cenários. 0 primeiro e mais simples é o cenário "população fechada”, que supõe uma população com saldo migratório nulo ao longo de todo o período de projeção. 0 segundo cenário foi nomeado "RDI 12" e baseia-se na análise de Pereima e Porsse (2013), que compararam 140 países a partir da relação entre a RDI e três variáveis: o crescimento do PIB, a taxa de investimento e a taxa de poupança. Fazendo uso do método não paramétrico Kernel-Epanechnikov por meio da estimativa de uma função densidade, os autores concluíram que todas elas se comportaram de maneira semelhante em suas associações com o indicador, mostrando uma relação positiva para baixos valores da RDI e negativa para altos valores. Os autores identificaram que a inversão de sentido na relação entre as variáveis analisadas para o crescimento do PIB ocorreu quando a RDI chegou a um valor próximo a 8, e para as duas outras variáveis, a 12. Assim, afirmam que:

[...] o crescimento econômico baseado em acumulação de capital começa se esgotar quando a razão de dependência de idosos ultrapassa a marca dos $8 \%$. Desta forma países cuja transição demográfica é tal que sua razão de dependência de idosos for maior que $8 \%$ e esteja crescendo começarão a experimentar restrições ao crescimento econômico (PEREIMA; PORSSE, 2013, p.57). 
Apesar de a análise feita pelos autores indicar que o ideal seria a manutenção de uma RDI em 8, já que assim garante-se um quadro positivo para os três indicadores associados, esse seria um cenário inviável. No Brasil, tal valor ocorreu no início da década de 1990. Assim, tentando aproximar a análise a ser feita do contexto nacional, optou-se por ter como objetivo a manutenção da RDI em 12.

O terceiro cenário analisado foi “atenuação da RDI”. Considerando o rápido crescimento da população idosa no Brasil nos próximos anos, Alves, Vasconcelos e Carvalho (2010) mostram que este levará ao estreitamento da base da estrutura etária e alargamento de seu topo de maneira acelerada. Embora tal contexto não seja exclusividade brasileira, torna-se interessante verificar a possibilidade de diminuir o ritmo de crescimento desse indicador. Esse seria um modo de suavizar o envelhecimento, mostrando-se um cenário menos audacioso do que o "RDI 12", apresentado anteriormente. Para tal, elaborou-se o cenário “atenuação da RDI”, buscando um país com características semelhantes, porém, com um ritmo de crescimento menor da RDI. Entre os países sul-americanos, o Chile foi considerado uma aproximação desse cenário, já que possui uma economia estável e também um fluxo migratório considerável, sem se aproximar da grandeza observada na Europa. A RDI chilena foi de 14,1 em 2010 (ONU, 2015) e chegará a 44,0 em 2050. Já no Brasil, as estimativas do IBGE (2013) apontam que esse indicador passará de 10,0 para 35,8 no mesmo intervalo de tempo. Como comparativamente o envelhecimento no Chile ocorrerá de forma mais lenta, suas taxas de crescimento foram utilizadas como parâmetro em busca da atenuação da RDI brasileira. Para tanto, a RDI brasileira foi suavizada utilizando a taxa de crescimento geométrico da RDI chilena, por meio da entrada de imigrantes, alcançando o valor de 31,5 em 2050. 0 intuito desse cenário foi puramente demográfico, objetivando verificar o impacto da componente demográfica sobre o envelhecimento populacional a partir da suavização do aumento da RDI.

Por fim, o último cenário analisado é denominado "TLM da Alemanha”, que supõe para - Brasil a mesma taxa líquida de migração estimada para a Alemanha nos próximos anos. A ONU (2015) define a TLM como a diferença entre o número de emigrantes e imigrantes durante um período, dividido pela população do país receptor nesse período. 0 principal intuito na elaboração desse cenário foi o de analisar quais os efeitos que ocorreriam no envelhecimento demográfico se o país assumisse uma TLM observável em locais com alta entrada de imigrantes. Assim, torna-se possível verificar o impacto de um aumento no fluxo migratório brasileiro na estrutura etária populacional. A Alemanha é um país que atualmente sofre com o acentuado envelhecimento populacional. Segundo estimativas da ONU, em 2010, enquanto a RDI brasileira foi inferior a 10, a alemã já alcançava o patamar de 31 idosos a cada 100 indivíduos em idade ativa. Esse quadro fez com que, ao longo do tempo, o país se tornasse adepto de políticas migratórias de estímulo à entrada de migrantes. Essa estratégia, conforme já explicitado, é feita ainda hoje com o intuito de suprir a demanda por mão de obra e estimular a economia do país. 
Considerando que a Alemanha realiza políticas de atração de imigrantes, inclusive para amenizar as consequências oriundas do envelhecimento populacional, o cenário "TLM da Alemanha" supõe que o Brasil tenha um comportamento semelhante e, portanto, consiga aumentar sua TLM e torne-se um país receptor no período analisado, assumindo que as TLM sejam equivalentes às estimadas para a Alemanha ao longo de todo o horizonte de projeção.

Os três cenários que propõem modificações no fluxo migratório têm alterações puramente demográficas, como exercícios que relacionam cenários de imigração ao enveIhecimento populacional. É importante salientar que os cenários propostos baseiam-se em saldos migratórios positivos e que, tendencialmente, são crescentes. Isso porque a própria imigração contribuirá para o envelhecimento populacional, já que se assume que os imigrantes considerados nos cálculos permanecem no país e nele envelhecem, além de assumirem as taxas de fecundidade e mortalidade nacionais. É preciso ressaltar ainda que, para a concretização de todos os cenários, seriam necessárias políticas relacionadas à atração e inserção dos imigrantes. Em um cenário de falta de abertura aos imigrantes, baixa inserção econômica e ausência de políticas migratórias, dificilmente o saldo migratório crescerá de maneira considerável conforme propõe a análise. Além disso, a única certeza dos cenários para a elaboração de projeções populacionais é que haverá erros, já que sua concretização depende de as hipóteses ocorrerem exatamente como descritas.

Certamente esses cálculos possuem vantagens e limitações. Uma das grandes vantagens é a de estimar, a partir de experiências empíricas de outras populações, quais seriam os potenciais efeitos de cenários de imigração para o Brasil em termos do envelhecimento populacional. Contudo, uma limitação importante é a de que cada país possui seu contexto histórico e social específico, influenciando as dinâmicas demográficas que também são particulares.

\section{Análise dos resultados}

O primeiro resultado das projeções demográficas elaboradas é o total de habitantes ao final do período, definido pela população inicial e pelos pressupostos assumidos ao longo do período. 0 Gráfico 1 traz esses resultados.

Esses resultados variam de maneira grandiosa, apresentando uma diferença de mais de um bilhão de indivíduos, observada entre os cenários "população fechada" e "RDI 12 ". Ou seja, apenas analisando o total de habitantes, concluímos que atingir o objetivo do cenário “RDI 12" demanda um número irrealizável de estrangeiros, fazendo com que a população do país alcance valores exorbitantes nas próximas décadas. Os números assemelham-se àqueles obtidos pela ONU (2001) para a manutenção da razão de suporte potencial da Coreia do Sul no nível mais alto observado desde 1995, em que a população coreana alcançaria mais de seis bilhões de habitantes em 2050. Claramente, esse resultando é irreal. A crítica de Coleman (2001) surge justamente nesse sentido, tratando os valores obtidos como 
impossíveis. Da mesma forma, o valor observado para o cenário "RDI 12" é praticamente impossível, já que também resulta em um tamanho populacional aproximadamente oito vezes superior ao da população atual.

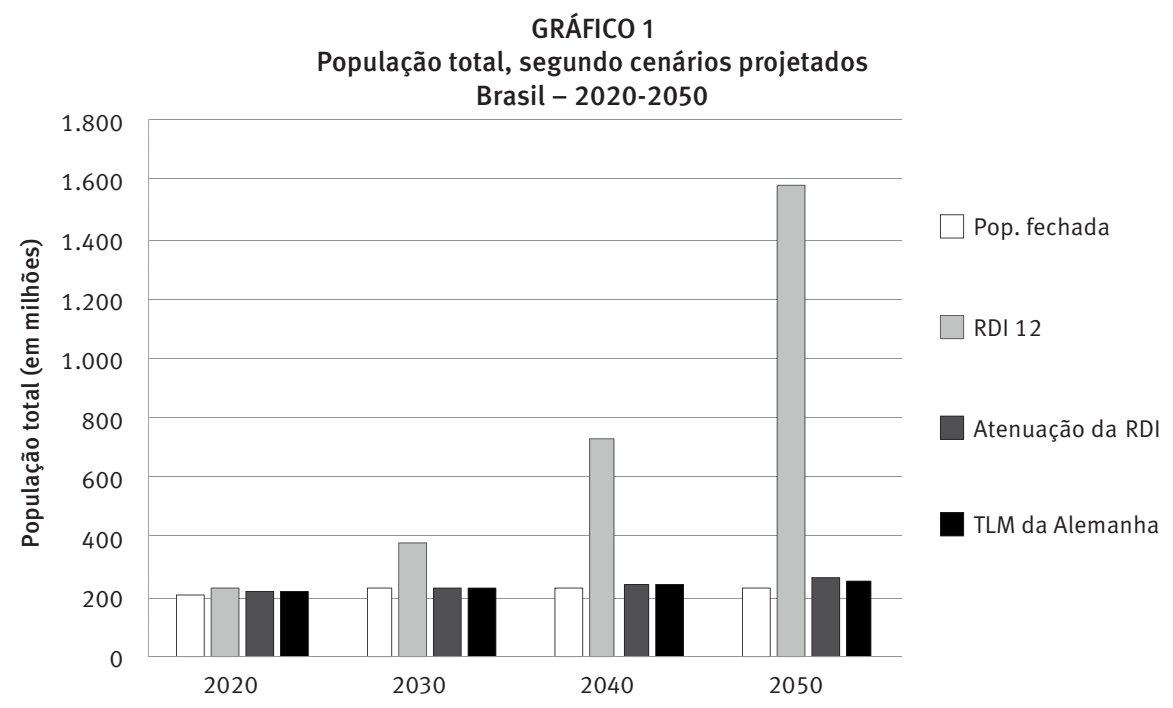

Fonte: IBGE. Elaboração dos autores.

Nota: População inicial da projeção em 2010 - IBGE (2013).

Ao longo dos anos os próprios imigrantes vão envelhecendo e, juntamente com os brasileiros, aumentam a proporção de idosos. Como o cenário "congela” o envelhecimento da estrutura etária, cada vez mais indivíduos em idade ativa são necessários para manter equilibrada no mesmo patamar a razão entre os idosos e a PIA. Por isso esse cenário resulta em uma população tão maior do que as demais, mostrando que interromper o envelhecimento populacional via migração, naqueles níveis, é uma tarefa muito pouco factível.

Os outros cenários crescem de maneira mais moderada. Depois do "RDI 12", o cenário "atenuação da RDI" é o que resulta no maior volume populacional, ultrapassando 260 milhões de habitantes, seguido pelos cenários "TLM da Alemanha", com cerca de 251 milhões de indivíduos, e "população fechada”, com 233 milhões de pessoas.

No que tange à RDI, apresentada no Gráfico 2, nota-se que, no início do período, apenas o cenário "RDI 12" se destaca dos demais, ficando abaixo dos outros ao longo de toda a análise, já que seu objetivo é manter o indicador no valor de 12. Já os outros cenários apresentam resultados bastante próximos. Apenas a partir de meados de 2030 esses resultados começam a se distanciar, alargando a diferença entre seus valores.

Excluindo o cenário que busca manter a RDI em 12, até o ano de 2028 o cenário "TLM da Alemanha” segue sendo aquele que resultou em uma RDI levemente mais baixa em relação ao restante. Apresentando um valor de 17,7 idosos para cada 100 indivíduos em idade ativa, esse cenário manteve-se abaixo dos valores dos cenários “população fechada” 
e “atenuação da RDI”, que alcançaram, respectivamente, 18,2 e 17,9 idosos por 100 indivíduos com idade entre 15 e 64 anos.

Assim, se for considerada apenas a contenção do envelhecimento populacional, o cenário "RDI 12" seria o melhor ao manter a RDI brasileira estagnada. Entretanto, os cenários “atenuação da RDI" e “TLM da Alemanha” são opções mais factíveis, ao amenizarem o crescimento do envelhecimento e resultarem em um crescimento populacional possível. 0 cenário “população fechada” resultou na maior RDI dentre todas as projeções, já que tanto a imigração como a fecundidade seguem tendências que fomentam o envelhecimento.

GRÁFICO 2

Razão de dependência de idosos, segundo cenários projetados Brasil - 2016-2050

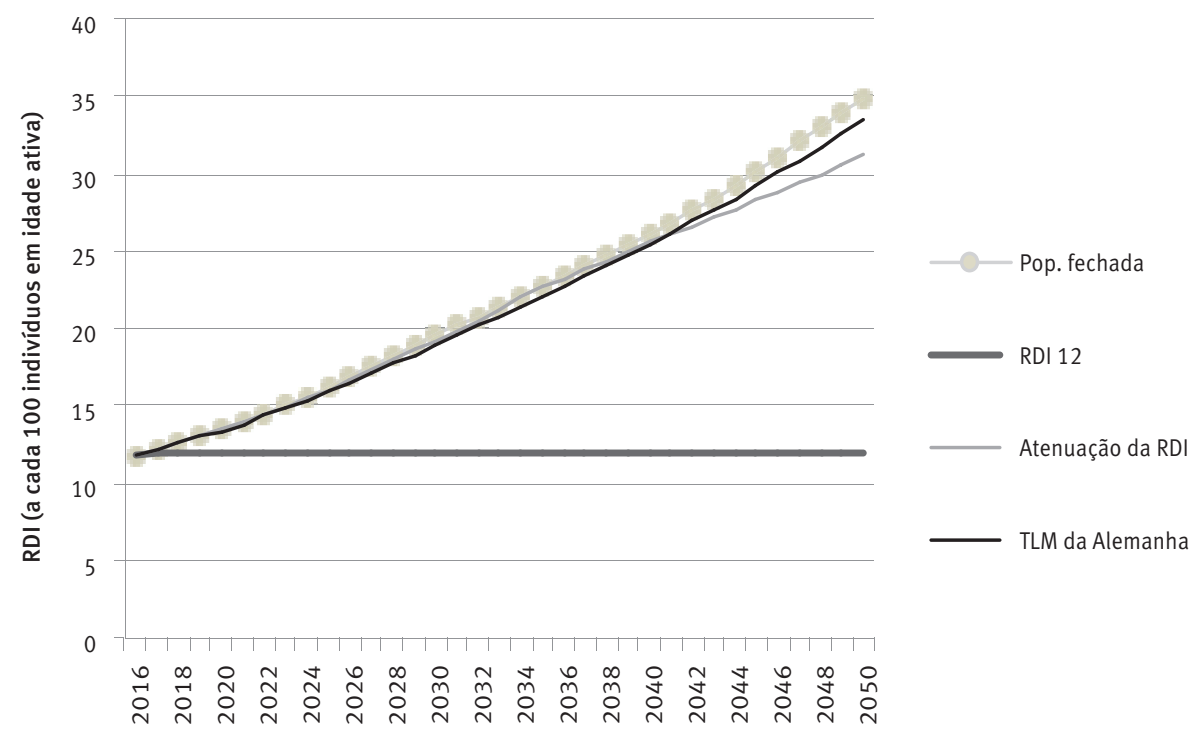

Fonte: IBGE. Elaboração dos autores.

Nota: População inicial da projeção em 2010 - IBGE (2013).

No que tange ao volume de imigrantes, conforme esperado, a TLM resultante do cenário "RDI 12" foi consideravelmente superior à dos demais desde o início da análise, alcançando o valor de 73,3 em 2050. Apenas nos três primeiros anos da projeção seria preciso gerar um saldo migratório de 20,4 milhões para manter a RDI brasileira em 12. Com o crescimento da população, a necessidade de estrangeiros para manter estável a RDI brasileira também se torna crescente, resultando, assim, em um saldo de quase 1,3 bilhão entre 2017 e 2050. Esse resultado reforça a impossibilidade do cenário, já que manter um saldo migratório anual médio de 36,6 milhões de pessoas no Brasil (ou em praticamente qualquer país) é uma dinâmica irreal, ainda mais improvável quando consideramos os atuais níveis do saldo migratório no país, próximos a zero (IBGE, 2018). 
Já para os cenários "atenuação da RDI” e "TLM da Alemanha”, nota-se que as TLMs são semelhantes no início do período projetado. Apenas próximo ao fim do horizonte de projeção os dois se afastam e a TLM do cenário "atenuação da RDI" passa a ser superior. Os resultados obtidos para esse cenário são bastante inferiores àqueles verificados para "RDI 12" e mostram-se mais razoáveis e passíveis de tornarem-se realidade, ao menos demograficamente, nos próximos anos. Tais dados estão dispostos na Tabela 6.

TABELA 6

TLM resultante, segundo cenários projetados

Brasil - 2020-2050

\begin{tabular}{lrrrrrrr}
\hline \multicolumn{1}{c}{ Cenários } & $\mathbf{2 0 2 0}$ & $\mathbf{2 0 2 5}$ & $\mathbf{2 0 3 0}$ & $\mathbf{2 0 3 5}$ & $\mathbf{2 0 4 0}$ & $\mathbf{2 0 4 5}$ & $\mathbf{2 0 5 0}$ \\
\hline RDI 12 & 28,8 & 40,0 & 48,5 & 55,2 & 62,2 & 68,8 & 73,3 \\
Atenuação da RDI & 2,1 & 1,8 & 0,0 & 0,0 & 3,1 & 7,3 & 7,1 \\
TLM da Alemanha & 1,9 & 1,9 & 1,9 & 1,9 & 2,0 & 2,0 & 2,0 \\
\hline
\end{tabular}

Fonte: IBGE. Elaboração dos autores.

Nota: População inicial da projeção em 2010 - IBGE (2013).

É evidente que a concretização de qualquer um dos cenários explicitados demanda mudanças radicais nas tendências observadas na componente migratória no Brasil. Um aumento tão considerável quanto os estimados na presente análise são resultados de mudanças significativas nos espaços da migração internacional, considerando-se, em última instância, alterações significativas na reestruturação produtiva em escala global (PATARRA, 2005) que fomentem o papel do país como receptor. De outro lado, a ocorrência do aumento do fluxo migratório também seria decorrente de estímulos à imigração para o país, bem como da integração dos imigrantes. Os cenários propostos trouxeram diversas dimensões referentes à migração de reposição enquanto estratégia de amenização do envelhecimento populacional brasileiro, sinalizando desafios e potencialidades dessa prática.

\section{Potencialidades da migração no mercado de trabalho}

Diante dos cenários analisados, nota-se que não há solução, nem mesmo a longo prazo, para a contenção do envelhecimento. Ainda que seja possível retardá-lo, é inevitável que a proporção de idosos aumente com o passar dos anos.

Conforme aponta Barbosa (2014, p. 305), a principal preocupação trazida pelas mudanças descritas diz respeito a "manter a força de trabalho em um tamanho suficiente para prover de forma eficiente os bens e serviços necessários para a população como um todo”. Projeções realizadas por Souza-Junior e Levy (2014) mostram que existe tendência de queda da PEA mesmo sob a hipótese de aumento da taxa de atividade feminina, que possui grande potencial de crescimento. Mesmo que o indicador no Brasil dos próximos anos se aproximasse ao experimentado atualmente pelos Estados Unidos, ainda assim haveria uma diminuição de 3\% na taxa de participação média entre 2010 e 2050. Caso não haja nenhuma mudança e o indicador permaneça no mesmo patamar, essa queda seria de 8\% (SOUZA-JUNIOR; LEVY, 2014). 
Em termos qualitativos, tais mudanças trazem preocupações em relação ao perfil do trabalhador nos próximos anos. Alves, Vasconcelos e Carvalho (2010) elaboraram projeções desse grupo e concluíram que, enquanto em 2010 a PEA jovem, que compreende as idades entre 15 e 24 anos, era 3,5 vezes superior àquela apontada como madura (composta pelos grupos de 50 a 59 anos de idade), 40 anos depois, em 2050, a PEA madura será $30 \%$ maior do que a jovem. Assim, o próprio mercado de trabalho nos próximos anos será envelhecido, podendo trazer consequências para a economia do país, impactando inclusive a produtividade.

Diante das discussões do presente artigo, os cenários apresentados mostram que a migração pode exercer influência sobre a estrutura etária da população brasileira, porém, sem reverter de maneira definitiva a tendência de envelhecimento. Ainda assim, apresenta um grande potencial em relação às preocupações ligadas ao mercado de trabalho, já que seria a maneira mais rápida de aumentar, em termos absolutos, a população em idade ativa. Uma vez concentrada nas idades ativas, a imigração poderia suprir os potenciais déficits do mercado de trabalho, tornando mais branda a queda no número de trabalhadores e suavizando o efeito da mudança no perfil etário dos trabalhadores.

Dessa forma, se a dinâmica demográfica em anos anteriores favoreceu o crescimento econômico do Brasil, as tendências apontam para um quadro com perspectivas preocupantes, mesmo sob hipóteses otimistas. Sendo assim, seria importante encarar a migração como uma variável relevante nesse processo, para que as transformações em curso sejam enfrentadas sem graves prejuízos econômicos.

Os pontos expostos trazem uma breve análise do impacto positivo que um aumento no saldo migratório pode ocasionar, principalmente em relação ao mercado de trabalho, considerando as dinâmicas colocadas pela questão do envelhecimento. Portanto, nos próximos anos, seria interessante ampliar os debates acerca do tema, fomentando a discussão sobre a relação migração e envelhecimento populacional.

\section{Considerações finais}

Os resultados apresentados no presente artigo buscaram retratar o impacto da componente migratória na estrutura etária brasileira dos próximos anos em alguns cenários. Dada a dificuldade inerente em prever com precisão a dinâmica demográfica em projeções, os cenários foram apenas ferramentas que possibilitaram analisar, especificamente, o impacto de determinadas dinâmicas migratórias. Ainda que os cálculos sob a forma de cenário sejam acompanhados de um grande grau de incerteza, as projeções populacionais são altamente utilizadas em estudos e essenciais como ferramentas de planejamento. Dessa maneira, seria melhor conhecer as possibilidades de futuro do que apenas esperar que ele aconteça e, assim, realizar o planejamento para tais possibilidades.

Diante do exposto, foi possível perceber que, mesmo em cenários que consideram um elevado volume de imigrantes, não há reversão definitiva das tendências do envelhecimento. 
Os cenários “atenuação da RDI” e "TLM da Alemanha”, apesar de estimarem um contingente considerável de imigrantes, apresentam uma RDI de, respectivamente, 31,2 e 33,5 em 2050, mostrando que as mudanças na estrutura etária são relativamente pequenas quando comparadas ao cenário "população fechada".

O cenário “atenuação da RDI” propõe justamente a diminuição do ritmo de crescimento da RDI brasileira. 0 fluxo migratório estimado, de fato, tem impacto sobre a pressão dos grupos de idade mais avançada e, ainda que aumente o fluxo direcionado ao Brasil, não chega, em termos quantitativos, aos valores observados no cenário "TLM da Alemanha”. A suposição de uma TLM brasileira semelhante à de um país receptor de migrantes certamente é audaciosa, sendo, porém, necessária para verificar o potencial impacto dessa componente. A Alemanha, que é um país já incluído nas rotas das migrações internacionais há alguns anos, viu esse aumento no fluxo acontecer devido a crises humanitárias em países próximos, sendo parte de dinâmicas da área de origem. Sendo assim, é difícil prever se algo semelhante acontecerá no Brasil nos próximos anos, já que as migrações são fatos sociais totais, complexos, que dizem respeito à sociedade como um todo, tanto historicamente como em termos sincrônicos, da estrutura social (SAYAD, 1998). Nesse sentido, a atual crise venezuelana e sua relação com as dinâmicas do Brasil poderiam influenciar a ampliação da capacidade de atração do Brasil. Entretanto, sem políticas atrativas e receptoras para estrangeiros - ações pouco prováveis no atual governo brasileiro - ainda que o Brasil já receba venezuelanos, o aumento desse número a ponto de alcançar o cenário "TLM da Alemanha” torna-se distante da realidade brasileira.

Ainda em relação às próximas décadas, apesar da dificuldade em prever a componente migratória devido à sua relação com variáveis bastante voláteis como momentos político, econômico e social, sem nenhuma alteração significativa, as estimativas indicam um saldo migratório próximo a zero. A crise econômica vivenciada nos últimos anos, associada ao desemprego, reforça essa possibilidade, já que o país permanece pouco atrativo para estrangeiros. Se não há expansão da economia e do mercado de trabalho, é difícil considerar que o fluxo migratório para o Brasil aumente e, mais ainda, que seja em grandeza suficiente para influenciar o enveIhecimento populacional.

Somado a esse contexto, o debate político sobre as migrações no país ainda é incipiente. Apesar de a Nova Lei de Migração ter sido um passo importante, não há uma perspectiva essencialmente humanitária que possibilite um aumento considerável nos fluxos migratórios, buscando atrair e integrar o imigrante em todas as esferas da sociedade. Sem tais modificações em direção a um país atrativo, os cenários aqui apresentados tornam-se improváveis e, como um dos resultados, o envelhecimento populacional e suas consequências econômicas e sociais ocorrerão de maneira mais acelerada.

De fato, a reversão do envelhecimento populacional é inviável. Ceteris paribus, mesmo sua atenuação em função dos fluxos migratórios, ainda que plausível, é relativamente improvável. Ainda que as preocupações relacionadas ao aumento de casos de xenofobia e perda de identidade cultural sejam fortes limitações do uso da migração de reposição, o debate acerca 
do tema e o esclarecimento de suas vantagens poderiam fomentar a própria questão, evidenciando ganhos econômicos e demográficos (além das próprias dinâmicas sociais e culturais).

Embora as potencialidades da migração em relação ao envelhecimento gerem efeitos quase que imediatos, com impactos demográficos e econômicos, a questão não pode ser analisada de modo isolado. Se, por um lado, a atração de imigrantes minimiza os impactos da transição da distribuição etária da população, por outro, a dinâmica social e econômica é crucial para que esse efeito seja possível.

\section{Referências}

ALVES, J. E. D. Transição demográfica, transição da estrutura etária e envelhecimento. Revista Portal de Divulgação, ano IV, n. 40, p. 8-15, 2014.

ALVES, J. E. D.; VASCONCELOS, D. S.; CARVALHO, A. A. Estrutura etária, bônus demográfico e população economicamente ativa no Brasil: cenários de longo prazo e suas implicações para o mercado de trabalho. Comissão Econômica para a América Latina e o Caribe (Cepal), Instituto de Pesquisa Econômica Aplicada (Ipea), 2010 (Texto para discussão, 10).

ARANGO, J. Las migraciones internacionales em un mundo globalizado. Vanguardia Dossier, n. 22, p. 6-15, 2007.

$\mathrm{BACCI}, \mathrm{M}$. L. Breve historia de las migraciones. Traducción: Marco Aurelio Galmarini. Madrid: Alianza Editorial, 2012.

BAENINGER, R.; SILVA, J. C. J. (org.). Migrações venezuelanas. Campinas: Nepo/Unicamp, 2018.

BARBOSA, A. L. N. de H. Um retrato de duas décadas do mercado de trabalho brasileiro. In: CAMARANO, A. A. Novo regime demográfico: uma nova relação entre população e desenvolvimento? Rio de Janeiro: Ipea, 2014. p. 271-309.

BEAUJOT, R. Effect of immigration on the Canadian population: replacement migration? PSC Discussion Papers Series, v. 17, n. 3, 2003.

BIJAK, J.; KUPISZEWSKA, D.; KUPISZEWSKI, M. Replacement migration revisited: simulations of the effects of selected population and labor market strategies for the aging Europe, 20022052. Population Research and Policy Review, v. 27, n. 3, p. 321-342, 2008.

BONGAARTS, J.; SOBOTKA, T. A demographic explanation for the recent rise in European fertility. Population and Development Review, v. 38, n. 1, p. 83-120, 2012.

BRASIL. Secretaria Nacional de Justiça. Refúgio em números. Brasília, 2017.

BRITO, F.; CARVALHO, J. A. M.; BAENINGER, R.; TURRA, C. M.; QUEIROZ, B. L. A transição demográfica e as políticas públicas no Brasil: crescimento demográfico, transição da estrutura etária e migrações internacionais. Belo Horizonte, 2007.

BRITO, F. Transição demográfica e desigualdades sociais no Brasil. Revista Brasileira de Estudos de População, São Paulo, v. 25, n. 1, p. 5-26, 2008.

CAMARANO A. A. Os novos idosos brasileiros: muito além dos 60? Rio de Janeiro: Ipea. 2004

CAMARANO A. A. Como a história tratou a relação entre população e desenvolvimento econômico. In: CAMARANO, A. A. Novo regime demográfico: uma nova relação entre população e desenvolvimento? Rio de Janeiro: Ipea, 2014a. p. 43-79. 
CAMARANO A. A. Perspectivas de crescimento da população brasileira e algumas implicações. In: CAMARANO, A. A. Novo regime demográfico: uma nova relação entre população e desenvolvimento? Rio de Janeiro: Ipea, 2014b. p. 177-210.

CAMARANO, A. A.; KANSO, S.; FERNANDES, D. A população brasileira e seus movimentos ao longo do século XX. In: CAMARANO, A. A. Novo regime demográfico: uma nova relação entre população e desenvolvimento? Rio de Janeiro: Ipea, 2014a. p. 177-210.

CAMARANO, A. A.; KANSO S.; FERNANDES, D. Menos jovens e mais idosos no mercado de trabalho? In: CAMARANO, A. A. Novo regime demográfico: uma nova relação entre população e desenvolvimento? Rio de Janeiro: Ipea, 2014b. p. 377-406.

CANEN, A. Currículo para o desafio à xenofobia: algumas reflexões multiculturais na educação. Conhecimento \& Diversidade, v. 6, n. 11, p. 89-98, 2014.

CAMAROTA, S. A.; ZEIGLER, K. Immigrant and native fertility 2008 to 2017. Washington, DC: Center for Immigration Studies, 2019.

CARVALHO, J. A. M. de; GARCIA, R. A. O envelhecimento da população brasileira: um enfoque demográfico. Cadernos de Saúde Pública, Rio de Janeiro, v. 19, n. 3, p. 725-733, jun. 2003.

CARVALHO, J. A. M.; BRITO, F. A demografia brasileira e o declínio da fecundidade no Brasil: contribuições, equívocos e silêncios. Revista Brasileira de Estudos de População, v. 22, n. 2, p. 351-369, 2005.

CARVALHO, J. A. M.; WONG, L. R. A window of opportunity: some demographic and socio-economic implications of the rapid fertility decline in Brazil. Belo Horizonte: Cedeplar, Universidade Federal de Minas Gerais, 1995.

CARTER, M. Fertility of Mexican immigrants women in the U.S.: a closer look. Social Science Quarterly, Austin, v. 81, n. 4, p. 1074-1086, 2000.

CARVALHO, J. A. M. de; GONÇALVES, G. Q.; SILVA, L. G. de C. e. Aplicação da técnica P/F de Brass em um contexto de rápida queda da fecundidade adolescente: 0 caso brasileiro na primeira década do século. In: ENCONTRO NACIONAL DE ESTUDOS POPULACIONAIS, 20., 2016, Foz do Iguaçu. Anais [...]. Belo Horizonte: Associação Brasileira de Estudos Populacionais (Abep), 2016.

CARVALHO, J. A. M. de. 0 saldo dos fluxos migratórios internacionais no Brasil na década de 80: uma tentativa de estimação. In: PATARRA, N. L. (coord.). Emigração e imigração internacionais no Brasil contemporâneo. Campinas: FNUAP; São Paulo: Oficina Editorial, 1996. p. 227-238.

CASTANHEIRA, H. C.; KOHLER, H. P. It is lower than you think it is: recent total fertility rates in Brazil and possibly other Latin American countries. In: POPULATION ASSOCIATION OF AMERICA ANNUAL MEETING, 2016, Washington. Proceedings [...]. Silver Spring: PPA, 2016.

CEPAL. Transformaciones demográficas y su influencia en el desarrollo en América Latina y el Caribe. Santiago de Chile: Cepal, 2008. Disponivel em: 〈https://repositorio.cepal.org/ handle/11362/2894>.

COLEMAN, D. A. Replacement migration, or why everyone is going to have to live in Korea: a fable for our times from the United Nations. Philosophical Transactions of the Royal Society of London B: Biological Sciences, v. 357, n. 1420, p. 583-598, 2001.

ERVATTI, L. R.; BORGES, G. M.; JARDIM, A. P. Mudança demográfica no Brasil no início do século XXI: subsídios para as projeções da população. Rio de Janeiro: IBGE, 2015.

FÍGOLI, M. G. B.; WONG, L. R. El camino hacia la estabilización demográfica y el proceso de envejecimiento en América Latina: una ilustración a partir de algunos países seleccionados. Papeles de Población, Toluca, v. 9, n. 35, p. 31-45, ene./mar. 2003. 
GOLDBERG, D. Another look at the Indianapolis fertility data. Milbank Memorial Fund Quarterly, v. 38, n. 1, p. 23-36, 1960.

GOLDSTEIN, S. Interrelations between migration and fertility in Thailand. Demography, v.10, n. 2, p. 225-241, 1973.

HERVITZ, H. M. Selectivity, adaptation, or disruption? A comparison of alternative hypotheses on the effects of migration on fertility: the case of Brazil. International Migration Review, v. 19, n. 2, p. 293-317, 1985.

IBGE - Instituto Brasileiro de Geografia e Estatística. Projeções da população: Brasil e Unidades da Federação. Rio de Janeiro: IBGE, 2013.

IBGE - Instituto Brasileiro de Geografia e Estatística. Projeções da população: Brasil e Unidades da Federação. Rio de Janeiro: IBGE, 2018.

IOTTI, L. H. A política imigratória brasileira e sua legislação: 1822-1914. In: X ENCONTRO ESTADUAL DE HISTÓRIA. Anais [...]. Santa Maria, Rio Grande do Sul: Universidade Federal de Santa Maria, 2010.

KAHN, J. Immigrant and native fertility during the 1980s: adaptation and expectations for the future. International Migration Review, Staten Island, v. 28, n. 3, p.501-519, Autumn 1994.

KULU, H. Migration and fertility: competing hypotheses re-examined. European Journal of Population, v. 21, n. 1, p. 51-87, 2005.

LEE, R. D. The formal demography of population ageing, transfers, and the economic life cycle. In: MARTIN, L. G.; PRESTON, S. H. (ed.). Demography of ageing. Washington, DC: National Academy Press, 1994. p. 8-49.

LEVY, M. S. F. O papel da migração internacional na evolução da população brasileira (1872 a 1972). Revista de Saúde Pública, São Paulo, v. 8, supl., p. 49-90, 1972.

MACISCO, J. J.; BOUVIER, L. F. R.; WELLER, H. The effect of labor force participation on the relation between migration status and fertility in San Juan, Puerto Rico. Milbank Memorial Fund Quarterly, v. 48 , n. 1, p. 51-70, 1970.

MARTES, A. C. B. Emigração brasileira: formação de mercados de consumo de produtos brasileiros no exterior. Revista de Administração de Empresas, v. 8 n. 1 p. 8-12, 2001.

MARTINE, G. A globalização inacabada: migrações internacionais e pobreza no século 21. São Paulo em Perspectiva, São Paulo, v. 19, n. 3, p. 3-22, 2005.

MAYER, J.; RIPHAHN, R. T. Fertility assimilation of immigrants: evidence from count data models. Bonn: Institute for the Study of Labor (IZA), 1999 (IZA Discussion Papers, n. 52).

MCKEOWN, T. Fertility, mortality and causes of death. An explanation of issues related to modern rise of population. Population Studies, v. 32, n. 3, p. 535-542, 1978. Disponivel em: 〈http://www. jstor.org/stable/2173726>.

MEYERSON, F. A. Replacement migration: a questionable tactic for delaying the inevitable effects of fertility transition. Population \& Environment, v. 22, n. 4, p. 401-409, 2001.

NAÇÕES UNIDAS. Métodos para preparar projeções de população por sexo e idade - Manual III. Rio de Janeiro: IBGE, 1978.

NOTESTEIN, F. Population: the long view. In: SCHULTZ, T. W. Food for the world. Chicago: Universit of Chicago Press, 1945. 
OLIVEIRA, F. B.; BELTRÃO, K. I.; PINHEIRO, S. S.; PEYNEAU, F. P. L.; MENDONÇA, J. L. O. O idoso e a previdência social. In: CAMARANO, A. A. (org.). Os novos idosos brasileiros: muito além dos 60? Rio de Janeiro: Ipea, 2005. p. 411-426.

OLIVEIRA, A. T. Um panorama da migração internacional a partir do Censo Demográfico de 2010. REMHU - Revista Interdisciplinar da Mobilidade Humana, v. 21, n. 40, p. 195-210, 2013.

OLIVEIRA, A. T. R. Fluxos migratórios recentes no Brasil: o cenário pós-2008. In: OLIVEIRA, A. T. R. (org.). Fluxos migratórios no Brasil: movimentos internos e internacionais. Mauritius: Novas Edições Acadêmicas, 2017. p.64-76.

OLIVEIRA, A. T. R. Transição demográfica e migrações internacionais: o Brasil na rota dos países desenvolvidos? Plataforma Política Social, 2014 (Texto para discussão, n. 2).

OLIVEIRA, A. T. R. Migrações internacionais e políticas migratórias no Brasil. Cadernos OBMigra - Revista Migrações Internacionais, v. 1, n. 3, p. 252-278, 2015 a.

OLIVEIRA, A. T. R. O perfil geral dos imigrantes no Brasil a partir dos censos demográficos 2000 e 2010. Cadernos OBMigra - Revista Migrações Internacionais, v. 1, n. 2, p. 48-73, 2015b.

OLIVEIRA, A. T. R. de et al. Notas sobre a migração internacional no Brasil na década de 80. In: PATARRA, N. L. (coord.). Emigração e imigração internacionais no Brasil contemporâneo. Campinas: FNUAP; São Paulo: Oficina Editorial, 1996. p. 227-238.

ONU. STATISTICAL OFFICE. Standard country or area codes for statistical use. New York: United Nations, 1982.

ONU. Replacement migration: is it a solution to declining and agein populations? New York: United Nations, 2001.

ONU. International migration report 2013. New York: United Nations, 2013.

ONU. World population prospects: The 2015 revision, custom data acquired via website, 2015.

PAGE, A.; BEGG, S.; TAYLOR, R.; LOPEZ, A. D. Global comparative assessments of life expectancy: the impact of migration with reference to Australia. Bull World Health Organ, v. 85, n. 6, p. 7481, 2007.

PATARRA, N. L. Migrações internacionais de e para o Brasil contemporâneo - volumes, fluxos, significados e políticas. São Paulo em Perspectiva, v. 19, n. 3, p. 23-33, 2005.

PATARRA, N. L.; FERNANDES, D. Brasil: país de imigração? Revista Internacional em Língua Portuguesa - Migrações, v. 3, n. 24, p. 65-96, 2011.

PEREIMA, J. B.; PORSSE, A. Transição demográfica, acumulação de capital e progresso tecnológico: desafios para o crescimento brasileiro. Revista Economia \& Tecnologia, v. 9, n. 1, p. 49-60, 2013.

PRESTON, S.; HEUVELINE, P.; GUILLOT, M. Population projection. In: PRESTON, S.; HEUVELINE, P.; GUILLOT, M. Demography: measuring and modeling population processes. Oxford: WilleyBlackwell, 2001.

REUS-PONS, M.; KIBELE, E. U. B.; JANSSEN, F. Differences in healthy life expectancy between older migrants and non-migrants in three European countries over time. International Journal of Public Health, v. 62, n. 5, p. 531-540, 2017.

ROSA, M. J. V. Imigração e envelhecimento: ligações perigosas. Revista Migrações, n. 10, p. 183-184, 2012.

RUEDIGER, M. A. Análise e avaliação do desenvolvimento institucional da política de imigração no Brasil para o século XXI. Rio de Janeiro: Fundação Getúlio Vargas, 2015. 
SAAD, P. M.; MILLER, T.; MARTINEZ, C. Impacto de los cambios demográficos en las demandas sectoriales en América Latina. Revista Brasileira de Estudos de População, São Paulo, v. 26, n. 2, p. 237-261, 2009.

SAAD, P. M. Envelhecimento populacional: demandas e possibilidades na área de saúde. Séries Demográficas, v. 3, p. 153-166, 2016.

SAYAD, A. Imigração ou os paradoxos da alteridade. São Paulo: Edusp, 1998.

SEYFERT, G. Colonização e política migratória no Brasil Imperial. In: SALLES, T.; SALLES, M. R. R. (org.). Políticas migratórias: América Latina, Brasil e brasileiros no exterior. São Carlos: Editora Sumaré, EdUFSCar, 2002. p. 79-110.

SILVA, J. C. J.; BOGUS, L. M. M.; SILVA, S. A. G. J. Os fluxos migratórios mistos e os entraves à proteção aos refugiados. Revista Brasileira de Estudos de População, São Paulo, v. 34, n. 1, p. 15-30, 2017.

SILVA, B. N.; SILVA, S. B. de M.; COELHO, A. S.; SILVA, M. P. Estruturas etárias da população do Brasil e dos estados brasileiros. RDE - Revista de Desenvolvimento Econômico, v. 9, n. 16, p. 93-97, 2007.

SIMÕES, C. C. S. A transição da fecundidade no Brasil: análise de seus determinantes e as novas questões demográficas. São Paulo: Arbeit Factory Editora e Comunicação, 2006.

SOUZA-JUNIOR, J. R. de C.; LEVY, P. M. Impactos do novo regime demográfico brasileiro sobre o crescimento econômico (2010-2050). In: CAMARANO, A. A. Novo regime demográfico: uma nova relação entre população e desenvolvimento? Rio de Janeiro: Ipea, 2014. p. 213-240.

STAVENHAGEN, R. Racismo y xenofobia en tiempos de la globalización. Estudios Sociológicos, v. XII, n. 34, p. 9-16, enero/abril 1994.

THOMPSON, W. S. Population. American Journal of Sociology, n. 34, p. 959-975, 1929.

UMEZAKI, M.; OHTSUKA, R. Impact of rural-urban migration on fertility: a population ecology analysis in the Kombio, Papua New Guinea. Journal of Biosocial Science, v. 30, n. 3, p. 411-422, 1998.

VASCONCELOS, A. M. N.; GOMES, M. M. F. Transição demográfica: a experiência brasileira. Epidemiologia e Serviços de Saúde, Brasília, v. 21, n. 4, p. 539-548, 2012.

WONG, L. R.; CARVALHO, J. A. M.; AGUIRRE, A. Duración de la transición demográfica en América Latina y su relación con el desarrollo humano. Estudios Demográficos y Urbanos, v. 15, n. 1, p. 185-207, 2000.

ZENTENO, R. B. Transición demográfica en América Latina: tendencias y consecuencias sociales. Revista Mexicana de Sociología, v. 66, p. 239-254, 2004.

\section{Sobre os autores}

Helena Nobre de Oliveira é estatística e mestra em População, Território e Estatísticas Públicas pela Escola Nacional de Ciências Estatísticas (Ence/IBGE). Assistente de Pesquisa do Instituto de Pesquisa Econômica Aplicada (Ipea).

César Augusto Marques da Silva é sociólogo, com mestrado e doutorado em Demografia pela Universidade Estadual de Campinas. Professor do Programa de Pós-graduação em População, Território e Estatísticas Públicas da Escola Nacional de Ciências Estatísticas (Ence/IBGE). 
Antonio Tadeu Ribeiro de Oliveira é estatístico, com pós-doutorado no Departamento de Ecologia Humana e População da Universidade Complutense de Madri, doutor em Demografia pela Universidade Estadual de Campinas e mestre em Planejamento Urbano e Regional pelo Instituto de Pesquisa e Planejamento Urbano e Regional. Pesquisador do Instituto Brasileiro de Geografia e Estatística (IBGE) e pesquisador associado do Observatório das Migrações Internacionais (OBMigra/UnB).

\title{
Endereço para correspondência
}

\author{
Helena Nobre de Oliveira \\ Escola Nacional de Ciências Estatísticas/IBGE \\ Rua André Cavalcanti, 106 \\ 20231-050 - Rio de Janeiro-RJ, Brasil \\ César Augusto Marques da Silva \\ Escola Nacional de Ciências Estatísticas/IBGE \\ Rua André Cavalcanti, 106 \\ 20231-050 - Rio de Janeiro-RJ, Brasil \\ Antonio Tadeu Ribeiro de Oliveira \\ Instituto Brasileiro de Geografia e Estatística (IBGE) \\ Avenida República do Chile, 500 8ํandar \\ 20031-170 - Rio de Janeiro-RJ, Brasil
}

\section{Abstract}

International migration: an alternative to the impacts of demographic changes in Brazil?

Demographic transition brings innumerable transformations in age structure, one of them being population ageing. In Brazil, it is estimated that $22.6 \%$ of the population will be 65 years of age, and older, by 2050 , in a similar scenario to that of developed countries. Given these changes, the limitations and potentials of migration are discussed as a possible way to address the situation. On the one hand, immigrants can become part of the active working-age population, constituting an important part of the future Brazilian workforce. On the other hand, it raises concern about the country absorbing foreigners, who will also age, thus increasing the weight of the older ages. In this context, the term "replacement migration" refers to the migratory process with demographic intent related to population size and structure. Therefore, in order to analyze the impact of the migratory component on Brazilian age structure up to the year 2050, demographic projections were prepared from scenarios based on the Demographic Component Method. The scenarios which aimed to decrease dependency ratio or were based on net migration rates of migrant recipient countries, such as Germany, were the ones which resulted in more reasonable migratory balances.

Keywords: Replacement migration. Population-ageing. Demographic transition. 


\section{Resumen}

Inmigración internacional: ¿una alternativa para los impactos de los cambios demográficos en Brasil?

La transición demográfica trae consigo innumerables transformaciones en la estructura etaria, de las cuales el envejecimiento poblacional es una. En Brasil, se estima que el 22,6 \% de la población tendrá 65 años o más en 2050, en un escenario similar al actual de los países desarrollados. Ante estos cambios, se debaten los límites y potencialidades de la migración como una posible forma de amenizar esa situación. Por un lado, los inmigrantes pueden integrar a la población en edad activa y constituir una parte importante de la mano de obra brasileña futura. Por otro lado, emerge la preocupación acerca de que el país sea capaz de absorber a esos extranjeros y que, más tarde, estos también envejecerán, aumentando el peso de las edades más envejecidas. En este contexto, surge el término migración de remplazo, que refiere al proceso migratorio con propósito demográfico relativo a la estructura de edad o tamaño poblacional. De esta forma, para analizar el posible impacto del componente migratorio sobre la estructura etaria brasileña hasta el año 2050, se elaboraron proyecciones demográficas a partir de distintos escenarios con base en el método de los componentes demográficos. Los escenarios que objetivaron la atenuación de la razón de dependencia o se basaron en tasas netas de migración de países receptores de migrantes, como Alemania, fueron los que resultaron en saldos migratorios más razonables.

Palabras clave: Migración de reemplazo. Envejecimiento poblacional. Transición demográfica.

Recebido para publicação em 01/08/2018 Aceito para publicação em 05/08/2019 